\title{
Bactericidal and Virucidal Activities of Biogenic Metal-Based Nanoparticles: Advances and Perspectives
}

\author{
Gonzalo Tortella ${ }^{1,2, *}$, Olga Rubilar ${ }^{1,2}$, Paola Fincheira ${ }^{1}$, Joana C. Pieretti ${ }^{3}$, Paola Duran ${ }^{4}$, \\ Isabella M. Lourenço ${ }^{3}$ (D) and Amedea B. Seabra ${ }^{3}$ (D) \\ 1 Centro de Excelencia en Investigación Biotecnológica Aplicada al Medio Ambiente (CIBAMA), Facultad de \\ Ingeniería y Ciencias, Universidad de La Frontera, Av. Francisco Salazar 01145, Temuco 4811230, Chile; \\ olga.rubilar@ufrontera.cl (O.R.); p.fincheira01@ufromail.cl (P.F.) \\ 2 Departamento de Ingeniería Química, Universidad de La Frontera, Av. Francisco Salazar 01145, Casilla 54-D, \\ Temuco 4811230, Chile \\ 3 Center for Natural and Human Sciences, Universidade Federal do ABC, Santo André 09210-580, Brazil; \\ joana.pieretti@ufabc.edu.br (J.C.P.); isabella.lourenco@ufabc.edu.br (I.M.L.); \\ amedea.seabra@ufabc.edu.br (A.B.S.) \\ 4 Biocontrol Research Laboratory, Scientific and Technological Bioresource Nucleus, Universidad de \\ La Frontera, Temuco 4811230, Chile; paola.duran@ufrontera.cl \\ * Correspondence: gonzalo.tortella@ufrontera.cl; Tel.: +56-45-2732414
}

\section{check for} updates

Citation: Tortella, G.; Rubilar, O.; Fincheira, P.; Pieretti, J.C.; Duran, P.; Lourenço, I.M.; Seabra, A.B. Bactericidal and Virucidal Activities of Biogenic Metal-Based

Nanoparticles: Advances and Perspectives. Antibiotics 2021, 10, 783. https://doi.org/10.3390/antibiotics 10070783

Academic Editor: Maria Fernanda N. N. Carvalho

Received: 2 June 2021

Accepted: 19 June 2021

Published: 28 June 2021

Publisher's Note: MDPI stays neutral with regard to jurisdictional claims in published maps and institutional affiliations.

Copyright: (c) 2021 by the authors. Licensee MDPI, Basel, Switzerland. This article is an open access article distributed under the terms and conditions of the Creative Commons Attribution (CC BY) license (https:// creativecommons.org/licenses/by/ $4.0 /)$.

\begin{abstract}
Much progress has been achieved in the preparation and application of engineered nanoparticles (NPs) in the field of medicine, mainly for antibacterial and antiviral applications. In the war against bacteria and viruses, besides traditional antibiotics and antiviral drugs, metal-based nanoparticles, such as silver (AgNPs), copper (CuNPs), copper oxides (CuO-NPs), iron oxide (FeO-NPs), zinc oxide ( $\mathrm{ZnO}-\mathrm{NPs})$, and titanium oxide $\left(\mathrm{TiO}_{2}-\mathrm{NPs}\right)$ have been used as potent antimicrobial agents. These nanoparticles can be synthesized by traditional methods, such as chemical and physical routes, or more recently by biogenic processes. A great variety of macro and microorganisms can be successfully used as reducing agents of metal salt precursors in the biogenic synthesis of metal-based NPs for antimicrobial activity. Depending on the nature of the biological agent, NPs with different sizes, aggregation states, morphology, surface coatings and charges can be obtained, leading to different antimicrobial effects. Considering the drug resistance to traditional therapies, the development of versatile nanomaterials with potent antimicrobial effects is under intensive investigation. In this sense, this review presents and discusses the recent progress in the preparation and application of metal-based nanoparticles biogenically synthesized for antibacterial and antivirus applications. The strength and limitations are critically discussed.
\end{abstract}

Keywords: antimicrobial nanoparticles; biogenic synthesis; metal nanoparticles; antibacterial; antivirus; nanobiotecnology

\section{Introduction}

In the last decades, engineered nanoparticles (NPs) have been extensively used in different fields such as electronic, medicine, pharmaceutical, agriculture, textiles, and cosmetics. Among them, metal-based nanoparticles such as silver (AgNPs), copper or copper oxides (CuNPs or CuO-NPs), iron oxide (FeO-NPs), gold (AuNPs), zinc oxide ( $\mathrm{ZnO}-\mathrm{NPs})$, and titanium oxide $\left(\mathrm{TiO}_{2}-\mathrm{NPs}\right)$ have received particular attention due to their impact in human health including several applications as antimicrobial agents [1,2]. These NPs can be prepared by different methods which impact the nanoparticle features and biological responses. Mainly, metal-based nanoparticles have been synthesized using chemical and physical routes [3-10]. These methods can be harmful to human health and to the environment, restricting their use in biomedical applications since that is where they are usually employed [11]. In a similar fashion, physical routes demand a high energy input. 
In contrast, eco-friendly alternatives have attracted the attention of the scientific community. In this direction, biogenic (or biological) methods are considered cost effective and non-toxic due to their simplicity and the absence of toxic reagents. In this regard, a plethora of biological resources have been evaluated in the biogenic synthesis of metalbased NPs (Figure 1) such as, plants, bacteria, yeast, fungi, macro and microalgae and waste materials [12-16].

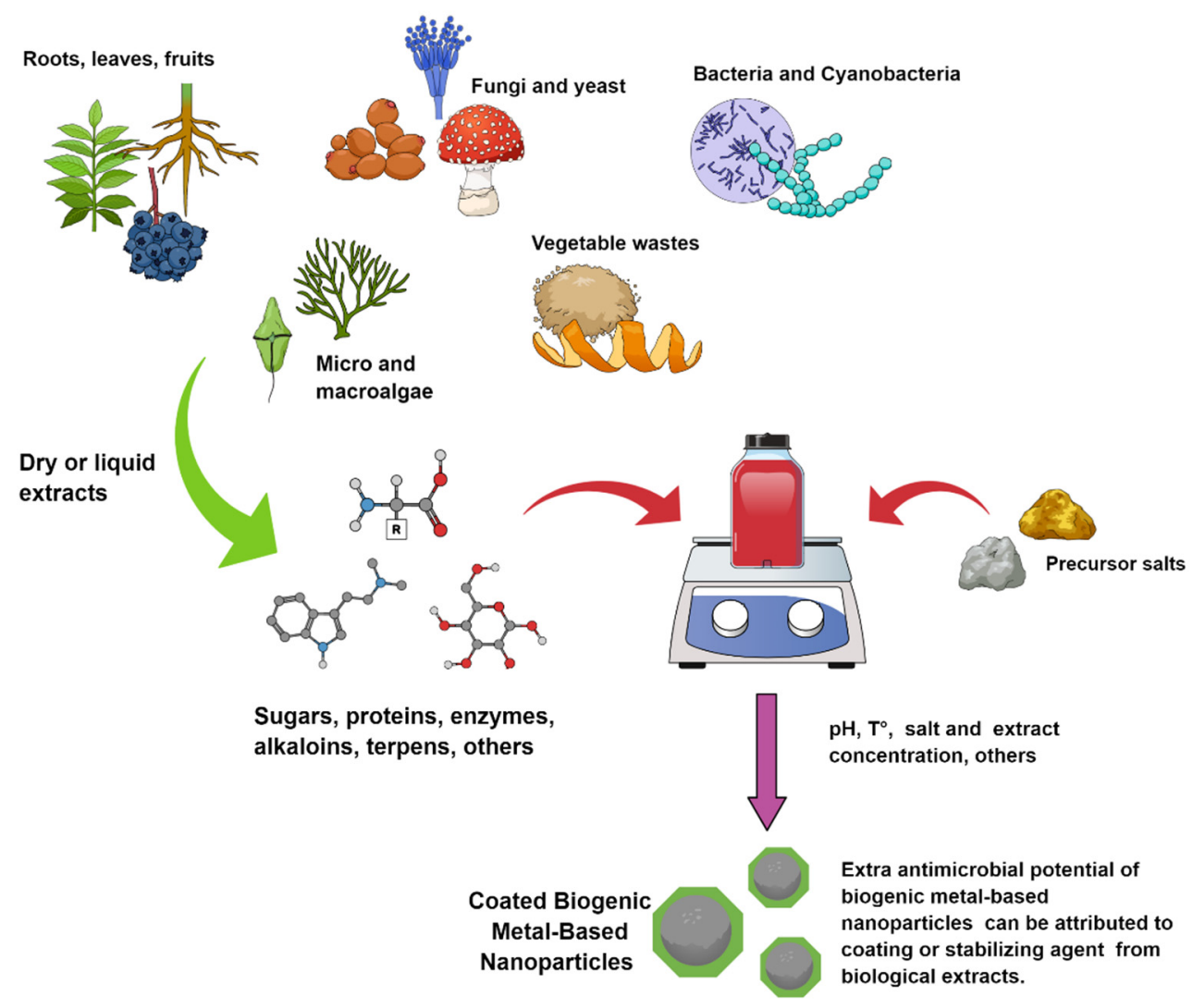

Figure 1. Main biological sources used to prepare biogenic metal-based NPs.

In a typical biogenic route, the biological entity acts not only as a reducing agent (yielding to the NPs), but also as a capping agent, coating the NPs surface, avoiding their oxidation, degradation and enhancing their biocompatibility $[17,18]$. In addition, depending on the nature of the biological entity used, an extra feature can be given to the NP's surface, such as an improvement of their antimicrobial activity, compared to the NPs synthesized by chemical or physical routes. For example, an improved antibacterial activity with lipoic acid capped AgNPs against Staphylococcus epidermidis and Streptococcus mutans, compared with AgNPs coated with polyethylene glycol or tannic was reported [19]. These biogenic synthesized NPs can find important biomedical and agricultural applications in the control of diseases caused by bacteria or viruses [2,20]. Indeed, in some cases, metal-based NPs, synthesized by biogenic routes, demonstrated higher antimicrobial activity related to the same metal-based NPs synthesized by the chemical route [21]. In the biogenic synthesis of nanomaterials, the biological entity acts not only as the reducing agent yielding the nanoparticles, but also as the capping agent of the obtained NP, avoiding NP aggregation and agglomeration. Moreover, depending on the chemical nature of the biological entity, an additional feature can be provided for the final nanomaterial, such as antioxidant and anti-inflammatory actions [22].

Biogenic metal-based NPs have shown to be efficient compared with common antiseptic agents used in medicine [23]. For instance, biogenic AgNPs incorporated into an ointment base have been used for the promotion of wound healing in the acceleration and suppression of wound infections. The formulation showed a quickly wound closure rate, 
as well as an efficient antiseptic in the wound infection bed against several pathogenic bacteria [24]. Biocompatibility assays in rats have shown that biogenic NPs did not represent a significant toxicity in terms of hematological and biochemical parameters, as well as an excellent biocompatibility with human red blood cells [25]. The antimicrobial mechanisms of action of metal-based NPs have been associated with the death of pathogens through membrane disintegration and the generation of reactive oxygen species (ROS) leading to cell death [26,27], as represented in Figure 2. In addition, the inhibition of bacterial kinase by biogenic $\mathrm{ZnO}$ NPs has been recently reported as a possible antimicrobial mechanism of action [28].

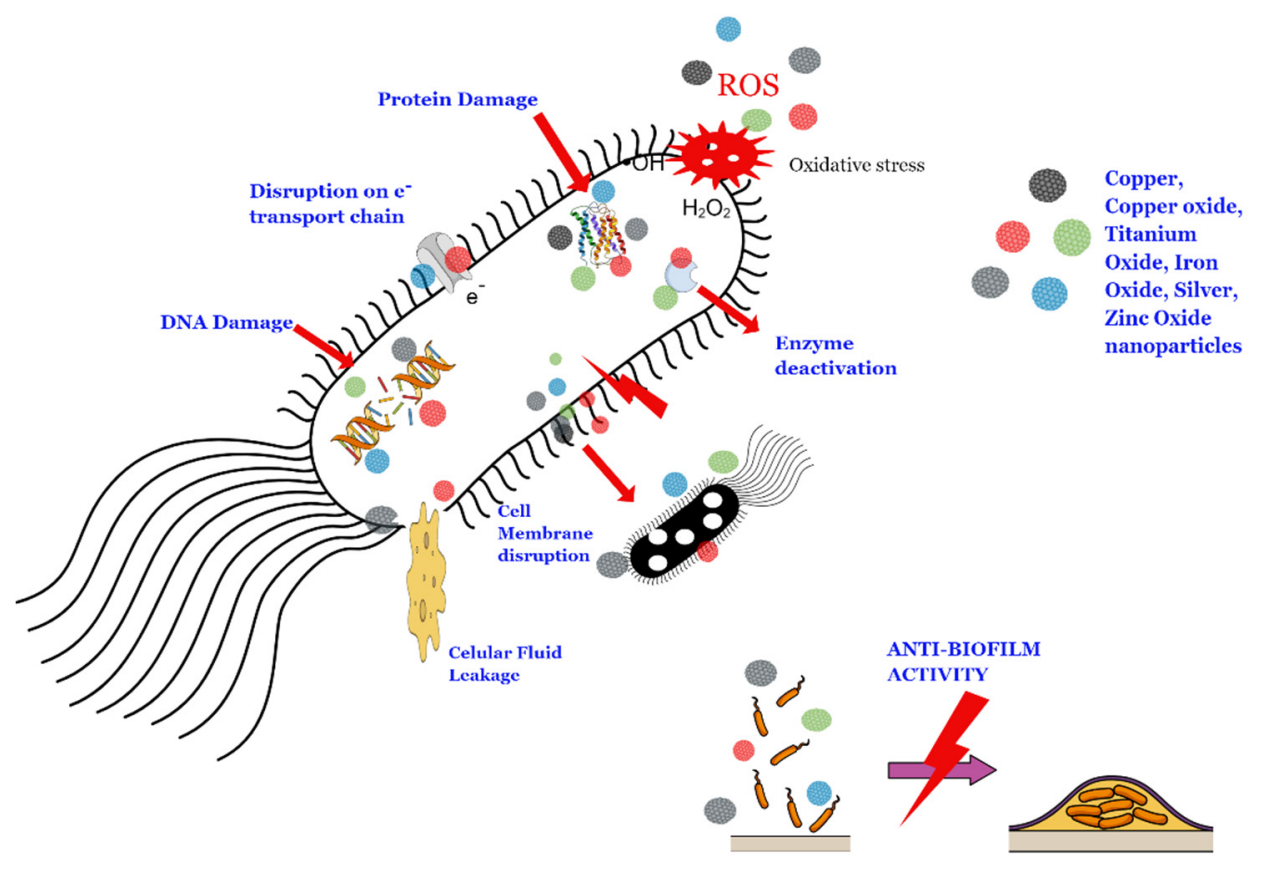

Figure 2. Schematic representation of the damage to bacterial cells caused by metal-based NPs.

The antiviral capacity of metal-based NPs has also been reported [2,29]. Biogenic nanoparticles have proved to be efficient against the Herpes Simplex virus (HSV-1), the Newcastle virus (NVD), the Coxsackievirus B4 virus, the hepatitis A virus, and the chikungunya virus, among others [17,30-33]. The proposed action mechanisms by which metalbased NPs can act against viruses are shown in Figure 3. Biogenic NPs also have a potent antimicrobial activity against plant pathogens. For instance, fruit extract AgNPs demonstrated excellent antimicrobial activities against Bacillus cereus and Pseudomonas syringae, as well as against Listeria monocytogenes and Staphylococcus aureus, for which they have been proposed as an excellent additive in food packaging materials $[34,35]$. Viral diseases in plants have been also reported [2]. In this regard, ZnO-NPs biogenically synthesized using Mentha spicata extract have proved to be an efficient treatment against the Tobacco Mosaic Virus (TMV) with a $90.21 \%$ reduction in the level of viral accumulation and disease severity in treated plants, compared with untreated ones [36]. 


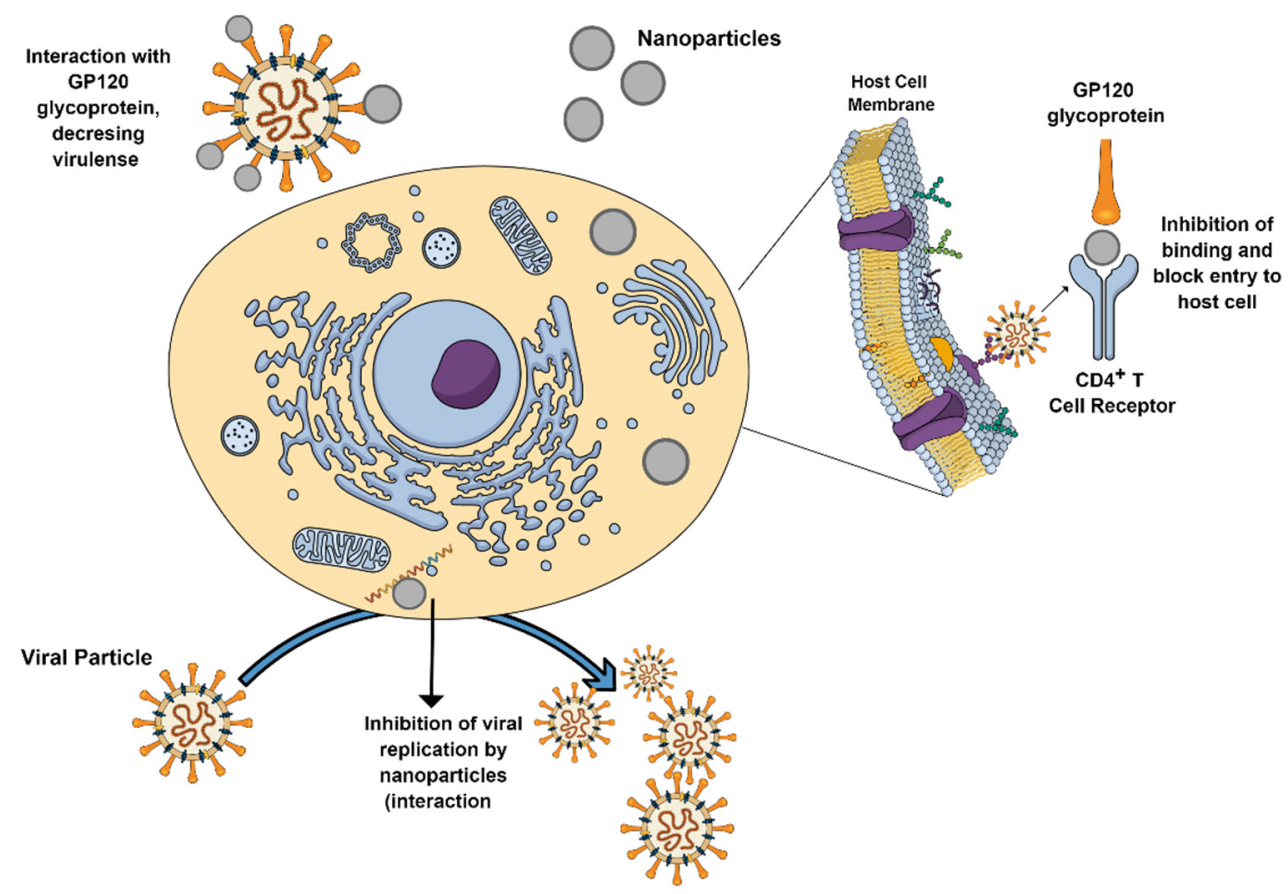

Figure 3. Main described action mechanisms by which metal-based NPs can act against viruses.

In this scenario, this review presents and discusses the current knowledge and advances in the last five years in the field of the antibacterial and antiviral activities of biogenic synthesized metal-based NPs. Moreover, new insights into the pathogenic resistance to biogenic NPs are also discussed.

\section{Biogenic Synthesis of Metal-Based NPs}

The biogenic synthesis of metal-based NPs has proved to be an innovative technology, biologically safe, biocompatible with the environment, and cost-effective compared to chemical and physical methods [37]. This method reduces the time of synthetic procedure, the costs, and provides the direct NP surface functionalization with the biological entities involved in the synthesis, which usually consists of an additional procedure in the physical or chemical synthesis [38,39].

Plant, bacteria, fungi, yeast, virus, and algae are the principal biological resources to biogenically synthesize metal-based NPs (Figure 1) [40]. The biogenic synthesis is based on metabolic processes carried out in plants and microorganisms to resist or adapt to the high concentration of toxic metals found in the environment $[37,41]$. Studies have reported the efficient use of reducing and stabilizing agents of microorganisms and plants by biological mass or extract for producing biogenic NPs through a sustainable technique [41]. The synthesis is carried out through the redox processes of metallic ions by secreted molecules such as sugar, carbohydrates, proteins, among others, but the full mechanism is not understood so far [40]. For instance, plant extracts are rich in polyphenols that act as strong reducing agents of metal ions leading to the formation of metallic NPs [42]. In addition, the reduction of metallic ions can be produced by cell components as amine, carbonyl, phenolic, pigments, terpenoids, alkaloids, among others. Nevertheless, the great chemical variety of metabolites involved in the reduction process makes it difficult to elucidate the mechanism of action [38]. Moreover, the experimental conditions (i.e., pH, temperature, reactant concentration, and reaction time) play an important role in the physical-chemical properties of the obtained NP [37].

As there are a great variety of biological entities needed to synthesize metal-based NPs, the ability and facility to easily scale up the production should be relevant in the choice of the best biogenic route [20]. In this sense, the use of plants as a resource to synthesize NPs offers important advantages compared to other biological entities, such as the low- 
cost effects, the ability to scale up the synthesis, and the presence of a greater number of active metabolites to the reduction process [43]. Furthermore, the biodiversity and the availability of different plant families with different profiles of primary and secondary metabolites contribute to the production of a greater variety of biogenic NPs with important antimicrobial applications [44]. Plant crude extracts are important sources of secondary metabolites such as flavonoids, terpenoids, alkaloids, phenol, steroids, saponins, among others, which can have anti-inflammatory, antioxidant, and antimicrobial activities [20]. Furthermore, plant extracts can be obtained from different parts of the plants, such as the seeds, stems, leaves, roots, shoots, flowers, and fruits. Consequently, the physicochemical properties of the obtained NPs nanoparticles depend on the species and the part of the plant used for the biosynthesis, which influence the NP shape, size, and surface. Diverse studies have reported the use of plant extracts to synthesize AgNPs, CuNPs, CuO-NPs, FeO-NPs, AuNPs, $\mathrm{ZnO}-\mathrm{NPs}$, and $\mathrm{TiO}_{2}-\mathrm{NPs}$, among others [11]. For instance, biogenic AgNPs and AuNPs were synthesized using plant extracts (Singh et al., 2018ab). Indeed, the plant species Acalypha indica, Eucalyptus citriodora, Garcinia mangostana, Morus, and Tanacetum vulgare were used to synthesize AgNPs with antimicrobial activity $[26,45]$. In a similar manner, the antimicrobial activity of ZnO NPs synthesized by plant extracts from Azadirachta indica, Trifolium pretense, Padina tetrastromatica, and Solanum nigrum, among others, has been reported [46]. In the same way, $\mathrm{TiO}_{2} \mathrm{NPs}$ synthetized with Azadirachta indica leaf extract have shown important antimicrobial activity [47].

In addition, microorganisms can biosynthesize NPs due to their reductase enzymes, which detoxify accumulated heavy metals [48]. Indeed, the microbial synthesis of NPs by secondary metabolites is performed at room temperature and pressure as part of an environmentally friendly and economic cost-effective approach [49]. Moreover, environmental conditions, such as stress conditions can trigger microorganisms, such as bacteria, to enhance their production of extracellular molecules aimed at their survival. These molecules are of particular interest for the generation of NPs. Microbial reductase enzymes can reduce metal salts to metal, and in most of the cases, this process can lead to NPs with a narrow size distribution. Overall, microorganisms can produce metal-based NPs through intracellular or extracellular routes [50]. The intracellular pathway is carried out by the ion transportation into the microbial cell for the metal ions to reduce to their elemental form by enzymes and electrostatic interactions. Meanwhile, the extracellular pathway involves the enzymatic reduction, which occurs on the cell surface or by the excretion of molecules able to reduce metal ions $[50,51]$. In a typical procedure, the extracellular synthesis is carried out by mixing the microbial culture filtrate and aqueous solution of the metallic salt. Meanwhile, intracellular synthesis involves the washing of microbial biomass and its incubation with a metal ion solution [41]. A variety of bacteria, yeast, and fungi have the ability to produce biogenic NPs with antimicrobial activity, such as Pseudomonas stutzeri, Bacillus subtilis, Escherichia coli, Aspergillus flavus, Fusarium oxysporum, Verticillium sp., and Schizosaccharomyces pombe, among others [52]. Furthermore, the live and dead biomasses of algae species have become increasingly relevant in the biogenic synthesis of NPs in the last few years. The algae species are characterized by having a good metal uptake [53]. The biosynthesis of NPs by the aqueous extract of algae is mediated by metabolites such as steroids, tannins, proteins, and polysaccharide, among others [53,54]. Factors such as their easy cultivation, fast growth, and the great possibility of production scaling have attracted attention in the biosynthesis of NPs mediated by algae species [55]. Interestingly, the screening of microalgae species for the biosynthesis of $\mathrm{Ag} / \mathrm{AgCl}$ nano hybrids with antibacterial effects has been reported [56]. The results indicated that Chlorella sp. was an effective resource for the biogenic synthesis of $\mathrm{Ag} / \mathrm{AgCl}$ nano hybrids with antibacterial activity in Bacillus species and E. coli [56].

Table 1 summarizes some relevant and recent research studies based on the biogenic synthesis of metal-based NPs using plant extracts (leaf, roots, and fruits), fungi, bacteria, algae, and oomycetes, among others. As stated before, the size distribution of metalbased NPs strongly depends on the bio-compounds present in the extract. The presence 
of a strong or weak reductant agent in the extract can promote a fast or slow reaction rate, favoring the formation of smaller or bigger NPs, respectively [57]. In this sense, the different optical bandgaps, energies, and morphologies of biogenic CuO-NPs depend on the nature of the vegetable extract waste used for the NP biosynthesis [58].

Table 1. Selected examples of biogenic metal-based NPs with antimicrobial activity synthesized by different biological sources. According to source: ${ }^{1}=$ Oomycete ${ }^{2}=$ Cyanobacterium, ${ }^{3}=$ Fungi, ${ }^{4}=$ Plant, ${ }^{5}=$ Algae, ${ }^{6}=$ Bacterial, ${ }^{7}=$ Microalgae .

\begin{tabular}{|c|c|c|c|c|c|c|}
\hline Metal & $\begin{array}{l}\text { Biocidal } \\
\text { Activity }\end{array}$ & $\begin{array}{l}\text { Biological Source } \\
\text { for the Synthesis }\end{array}$ & Size and Shape & Characterization & $\begin{array}{l}\text { Antimicrobial } \\
\text { Dose }\end{array}$ & Reference \\
\hline \multirow[t]{8}{*}{ Ag-NP } & \multirow[t]{6}{*}{ Bactericidal } & Pythium oligandrum ${ }^{1}$ & $\begin{array}{l}\text { Size: } 6-12 \mathrm{~nm} \\
\text { Shape: round }\end{array}$ & $\begin{array}{l}\text { UV-Vis; TEM; } \\
\text { XRD }\end{array}$ & $\begin{array}{c}0.088 \mathrm{mg} \mathrm{L}^{-1} \\
0.176 \mathrm{mg} \mathrm{L}^{-1} \\
0.44 \mathrm{mg} \mathrm{L}^{-1}\end{array}$ & [59] \\
\hline & & $\begin{array}{c}\text { Leptolyngbya sp. } \\
\text { WUC } 59^{2}\end{array}$ & Size: $20-35 \mathrm{~nm}$ & $\begin{array}{l}\text { UV-Vis; XRD; } \\
\text { FTIR; TEM; } \\
\text { EDXRF }\end{array}$ & $10 \mathrm{mg} \mathrm{L}^{-1}$ & [39] \\
\hline & & Fusarium scirpi ${ }^{3}$ & $\begin{array}{l}\text { Size: } 2-20 \mathrm{~nm} \\
\text { Shape: } \\
\text { quasi-spherical }\end{array}$ & $\begin{array}{l}\text { UV-Vis; FTIR; } \\
\text { TEM; EDXRF }\end{array}$ & $76 \mathrm{mg} \mathrm{L}^{-1}$ & [60] \\
\hline & & $\begin{array}{c}\text { Calligonum comosum } \\
\text { (roots) } \\
\text { Azadirachta indica }{ }^{4} \\
\text { (leaf extracts) }^{\text {Ale }}\end{array}$ & $\begin{array}{c}\text { Size: } 90-183 \mathrm{~nm} \\
\text { Shape: spherical and } \\
\text { aggregate }\end{array}$ & $\begin{array}{l}\text { FTIR; TEM; } \\
\text { SEM }\end{array}$ & $\begin{array}{l}10.9-21.41 \\
\mu \mathrm{g} \mathrm{mL}-1\end{array}$ & [61] \\
\hline & & Allium sativum $^{4}$ & $\begin{array}{c}\text { Size: } 13.13-22.69 \mathrm{~nm} \\
\text { Shape: spherical and } \\
\text { aggregated }\end{array}$ & $\begin{array}{l}\text { UV-Vis; SEM; } \\
\text { FTIR }\end{array}$ & $30 \mathrm{mg} \mathrm{mL}^{-1}$ & [62] \\
\hline & & $\begin{array}{l}\text { Trichodesmium } \\
\text { erythraeum }^{7}\end{array}$ & $\begin{array}{l}\text { Size: } 26.5 \mathrm{~nm} \\
\text { Shape: cubical }\end{array}$ & $\begin{array}{l}\text { TEM; XRD; } \\
\text { SEM; FTIR; } \\
\text { AFM }\end{array}$ & $\begin{array}{l}\text { MIC: } 50-75 \\
\mu g \mathrm{~mL}^{-1}\end{array}$ & [63] \\
\hline & \multirow[t]{2}{*}{ Virucidal } & $\begin{array}{l}\text { Panax ginseng } \\
\quad \text { (roots) }\end{array}$ & $\begin{array}{l}\text { Size: } 5-15 \mathrm{~nm} \\
\text { Shape: Spherical }\end{array}$ & $\begin{array}{l}\text { UV-Vis; XRD; } \\
\text { FTIR;TEM }\end{array}$ & $\begin{array}{c}0.005 \mathrm{M} \\
0.01 \mathrm{M} \\
0.15 \mathrm{M}\end{array}$ & {$[64]$} \\
\hline & & $\begin{array}{c}\text { Lampranthus } \\
\text { coccineus }^{4} \\
\text { Malephora lutea } 4\end{array}$ & $\begin{array}{c}\text { Size: } \\
\text { 10.12-27.89 nm } \\
\text { (L. coccineus) } \\
8.91-14.48 \mathrm{~nm} \\
\text { (M. lutea) } \\
\text { Shape: Spherical }\end{array}$ & $\begin{array}{l}\text { TEM; UV-Vis; } \\
\text { FTIR; SEM, } \\
\text { AFM, EDX; } \\
\text { XRD }\end{array}$ & $\begin{array}{c}\text { IC50: } 29.04-31.38 \\
\quad \mu g \mathrm{~mL}^{-1}\end{array}$ & [33] \\
\hline \multirow[t]{5}{*}{$\mathrm{Au}-\mathrm{NPs}$} & \multirow[t]{3}{*}{ Bactericidal } & Tinospora cordifolia ${ }^{4}$ & $\begin{array}{l}\text { Size: } 16.1 \mathrm{~nm} \\
\text { Shape: spherical and } \\
\text { polydisperse }\end{array}$ & $\begin{array}{l}\text { UV-Vis; FTIR; } \\
\text { XRD; EDX; } \\
\text { SEM; TEM. }\end{array}$ & $1000 \mu \mathrm{g} \mathrm{mL}^{-1}$ & {$[65]$} \\
\hline & & Codonopsis pilosula ${ }^{4}$ & $\begin{array}{l}\text { Size: } 20 \mathrm{~nm} \\
\text { Shape: } \text { spherical }\end{array}$ & $\begin{array}{l}\text { FTIR; XRD; } \\
\text { TEM; EDX. }\end{array}$ & & {$[66]$} \\
\hline & & Mangifera indica 4 & $\begin{array}{c}\text { Size: } 46.8 \mathrm{~nm} \\
\text { Shape: spherical }\end{array}$ & $\begin{array}{l}\text { SEM; TEM; } \\
\text { UV-Vis; XRD; } \\
\text { EDX. }\end{array}$ & $25-100 \mu \mathrm{g} \mathrm{mL}^{-1}$ & [67] \\
\hline & \multirow[t]{2}{*}{ Virucidal } & $\begin{array}{l}\text { Allium sativa }{ }^{4} \\
\text { (garlic extract) }^{\text {garlic }}\end{array}$ & $\begin{array}{c}\text { Size: } 6 \mathrm{~nm} \\
\text { Shape: Spherical }\end{array}$ & $\begin{array}{l}\text { UV-Vis; DLS; } \\
\text { TEM. }\end{array}$ & $\begin{array}{c}\text { EC50: } 8.829 \\
\mu g \mathrm{~mL}^{-1}\end{array}$ & {$[68]$} \\
\hline & & $\begin{array}{l}\text { Oscillatoria sp. }{ }^{5} \\
\text { Spirulina platensis }\end{array}$ & $\begin{array}{l}\text { Size: } 15.60-77.13 \mathrm{~nm} \text {. } \\
\text { Shape: Octahe- } \\
\text { dral, pentagonal and } \\
\text { triangular structures }\end{array}$ & $\begin{array}{l}\text { UV-Vis; XRD; } \\
\text { TEM; FTIR. }\end{array}$ & $31.25 \mu \mathrm{L}$ well ${ }^{-1}$ & [30] \\
\hline
\end{tabular}


Table 1. Cont.

\begin{tabular}{|c|c|c|c|c|c|c|}
\hline Metal & $\begin{array}{l}\text { Biocidal } \\
\text { Activity }\end{array}$ & $\begin{array}{l}\text { Biological Source } \\
\text { for the Synthesis }\end{array}$ & Size and Shape & Characterization & $\begin{array}{l}\text { Antimicrobial } \\
\text { Dose }\end{array}$ & Reference \\
\hline \multirow[t]{5}{*}{$\begin{array}{l}\text { Cu-NPs } \\
\text { CuO-NPs }\end{array}$} & Bactericidal & Cissus vitiginea $^{4}$ & $\begin{array}{l}\text { Size: } 20 \mathrm{~nm} \\
\text { Shape: } \\
\text { monodispersed } \\
\text { distribution }\end{array}$ & $\begin{array}{l}\text { UV-Vis; SEM; } \\
\text { XRD; TEM. }\end{array}$ & 25,50 and $75 \mu \mathrm{L}$ & [69] \\
\hline & & $\begin{array}{l}\text { Hagenia abyssinica } \\
\text { (Brace) JF. Gmel. }{ }^{4}\end{array}$ & $\begin{array}{c}\text { Size: } 34.76 \mathrm{~nm} \\
\text { Shape: mix of } \\
\text { spherical, hexagonal, } \\
\text { triangular, } \\
\text { cylindrical, and } \\
\text { irregularly particles }\end{array}$ & $\begin{array}{l}\text { UV-Vis; FTIR; } \\
\text { XRD; TEM; } \\
\text { EDXRF. }\end{array}$ & $\underset{\text { extract }}{1 \mathrm{mg} \mathrm{mL}^{-1}}$ & [70] \\
\hline & & Curcuma longa 4 & $\begin{array}{l}\text { Size: } 5-20 \mathrm{~nm} \\
\text { Shape: }\end{array}$ & $\begin{array}{l}\text { FESEM; SEM; } \\
\text { TEM; XRD; } \\
\text { EDXRD. }\end{array}$ & $100-250 \mu \mathrm{L}$ & [71] \\
\hline & & Garcinia mangostana ${ }^{4}$ & $\begin{array}{l}\text { Size: } 20-25 \mathrm{~nm} \\
\text { Shape: spherical and } \\
\text { agglomerated }\end{array}$ & $\begin{array}{l}\text { XRD; TEM; } \\
\text { SEM }\end{array}$ & $0.4-0.4 \mu \mathrm{g} \mathrm{mL}-1$ & {$[72]$} \\
\hline & Virucidal & $\begin{array}{c}\text { Syzygium } \\
\text { Alternifolium } \\
\text { (Fruit extract) }\end{array}$ & $\begin{array}{l}\text { Size: } 2-69 \mathrm{~nm} \\
\text { Shape: spherical and } \\
\text { agglomerated }\end{array}$ & - & - & [73] \\
\hline \multirow[t]{8}{*}{ ZnO-NPs } & Bactericidal & $\begin{array}{c}\text { Cassia fistula } \\
\text { Melia azadarach }\end{array}$ & $\begin{array}{l}\text { Size: 3-68 nm } \\
\text { Shape: spherical }\end{array}$ & $\begin{array}{l}\text { XRD; FTIR; } \\
\text { SEM; UV-Vis; } \\
\text { DLS. }\end{array}$ & $\begin{array}{c}50 \mu \mathrm{g} \mathrm{mL} \mathrm{m}^{-1} \\
(10 \mu \mathrm{L}) \text { to } 1000 \mu \mathrm{g} \\
\mathrm{mL}^{-1}(200 \mu \mathrm{L})\end{array}$ & [74] \\
\hline & & Banana peel extract ${ }^{4}$ & $\begin{array}{c}\text { Size: } 450 \times 24 \mathrm{~nm} \text {, } \\
210 \times 120 \mathrm{~nm}, \\
20-40 \mathrm{~nm} \\
430 \times 180 \mathrm{~nm} . \text { Shape: } \\
\text { flakes, nanocones, } \\
\text { pinecone-like } \\
\text { structure and cubic. } \\
\text { Size: } 50.95-54.84 \mathrm{~nm}\end{array}$ & $\begin{array}{l}\text { FTIR; GPC; } \\
\text { XRD; SEM; } \\
\text { TGA; QMS }\end{array}$ & $250 \mu \mathrm{g} \mathrm{mL}^{-1}$ & [75] \\
\hline & & Punica granatum ${ }^{4}$ & $\begin{array}{l}\text { Shape: polydispersity } \\
\text { of nanoparticles with } \\
\text { spikes on the surface, } \\
\text { irregular form }\end{array}$ & $\begin{array}{l}\text { XRD; UV-Vis; } \\
\text { TEM; FTIR; } \\
\text { EDXRD. }\end{array}$ & $5000 \mu \mathrm{g} \mathrm{mL}^{-1}$ & [76] \\
\hline & & Orange fruit peel ${ }^{4}$ & $\begin{array}{l}\text { Size: } 10-20 \mathrm{~nm} \\
\text { Shape: small and } \\
\text { spherical }\end{array}$ & $\begin{array}{l}\text { XRD; TGA; } \\
\text { TEM. }\end{array}$ & $0.025 \mathrm{mg} \mathrm{mL}^{-1}$ & [66] \\
\hline & & Magnoliae officinalis ${ }^{4}$ & $\begin{array}{c}\text { Size: } 150 \mathrm{~nm} \\
\text { Shape: spherical }\end{array}$ & $\begin{array}{l}\text { UV, FTIR, SEM, } \\
\text { XRD, EDX, DLS }\end{array}$ & $250 \mu \mathrm{g} \mathrm{mL}^{-1}$ & [77] \\
\hline & & $\begin{array}{c}\text { Matricaria chamomilla } \\
\text { L. }{ }^{4} \\
\text { Olea europea }{ }^{4} \\
\text { Lycopersicon } \\
\text { esculentum M. }{ }^{4}\end{array}$ & $\begin{array}{l}\text { Size: } 48.2 \mathrm{~nm} \\
\text { Shape: cubic } \\
\text { structures }\end{array}$ & $\begin{array}{l}\text { UV-Vis; XRD; } \\
\text { TEM; SEM. }\end{array}$ & $4-16 \mu \mathrm{g} \mathrm{mL}^{-1}$ & [78] \\
\hline & & Catharanthus roseus 4 & $\begin{array}{l}\text { Size: } 50.73 \mathrm{~nm} \\
\text { Shape: spherical }\end{array}$ & $\begin{array}{l}\text { UV-Vis; FTIR; } \\
\text { XRD; TEM; } \\
\text { SEM; EDX; } \\
\text { AFM; DLS. }\end{array}$ & $1500 \mu \mathrm{g} \mathrm{mL}^{-1}$ & {$[79]$} \\
\hline & Virucidal & - & - & - & - & - \\
\hline
\end{tabular}


Table 1. Cont.

\begin{tabular}{|c|c|c|c|c|c|c|}
\hline Metal & $\begin{array}{l}\text { Biocidal } \\
\text { Activity }\end{array}$ & $\begin{array}{l}\text { Biological Source } \\
\text { for the Synthesis }\end{array}$ & Size and Shape & Characterization & $\begin{array}{l}\text { Antimicrobial } \\
\text { Dose }\end{array}$ & Reference \\
\hline \multirow[t]{4}{*}{$\mathrm{TiO}_{2}-\mathrm{NPs}$} & Bactericidal & $\begin{array}{c}\text { Tricoderma } \\
\text { citrinoviride }^{3}\end{array}$ & $\begin{array}{l}\text { Size: } 10-400 \mathrm{~nm} \\
\text { Shape: irregular, } \\
\text { triangular, } \\
\text { pentagonal, spherical } \\
\text { and rod-shaped } \\
\text { particles }\end{array}$ & $\begin{array}{l}\text { UV-Vis; } \\
\text { FESEM; SEM; } \\
\text { FTIR; XRD; } \\
\text { DLS. }\end{array}$ & $50-100 \mu \mathrm{g} \mathrm{mL}^{-1}$ & [80] \\
\hline & & $\begin{array}{l}\text { Staphylococcus } \\
\text { aureus } 6\end{array}$ & $\begin{array}{l}\text { Size: } 10-30 \mathrm{~nm} \\
\text { Shape: spherical, } \\
\text { oval, and smooth } \\
\text { surface }\end{array}$ & $\begin{array}{l}\text { UV-Vis; XRD; } \\
\text { SEM; FTIR; } \\
\text { AFM; }\end{array}$ & $10-15 \mathrm{mg} \mathrm{mL}^{-1}$ & [81] \\
\hline & & Cola nitida ${ }^{4}$ & $\begin{array}{l}\text { Size: } 25-191 \mathrm{~nm} \\
\text { Shape: spherical }\end{array}$ & $\begin{array}{l}\text { UV-Vis; FTIR; } \\
\text { TEM; EDX. }\end{array}$ & $80 \mu \mathrm{g} \mathrm{mL}^{-1}$ & [82] \\
\hline & Virucidal & - & - & - & - & - \\
\hline \multirow[t]{5}{*}{ FeO-NPs } & Bactericidal & Pterocladia capillacea ${ }^{4}$ & $\begin{array}{l}\text { Size: } 11.24-33.71 \mathrm{~nm} \\
\text { Shape: nanospheres } \\
\text { Size: } 15-60 \mathrm{~nm}\end{array}$ & $\begin{array}{l}\text { FTIR; SEM; } \\
\text { EDXRD. }\end{array}$ & $30 \mathrm{mg} \mathrm{mL}^{-1}$ & [54] \\
\hline & & $\begin{array}{l}\text { Agrewia optiva } 4 \\
\text { Prunus pérsica }^{4}\end{array}$ & $\begin{array}{l}\text { Shape: rough } \\
\text { surfaces, } \\
\text { agglomerated, } \\
\text { quasi-spherical }\end{array}$ & $\begin{array}{l}\text { UV-Vis; FTIR; } \\
\text { XRD; SEM; } \\
\text { TEM; DLS. }\end{array}$ & $100 \mathrm{Ml} \mathrm{NPs}$ & [83] \\
\hline & & Zingiber officinale $k^{4}$ & $\begin{array}{c}\text { Size: } 56.2 \mathrm{~nm} \\
\text { Shape: agglomerated } \\
\text { and larger }\end{array}$ & $\begin{array}{l}\text { UV-Vis; FTIR; } \\
\text { XRD }\end{array}$ & $30 \mu \mathrm{g} \mathrm{mL}^{-1}$ & [84] \\
\hline & & Psidium guajava ${ }^{4}$ & $\begin{array}{c}\text { Size: } 34 \mathrm{~nm} \\
\text { Shape: } \\
\text { quasi-spherical }\end{array}$ & $\begin{array}{l}\text { XRD; UV-Vis; } \\
\text { FTIR; SEM; } \\
\text { TEM; VSM. }\end{array}$ & $20-100 \mu \mathrm{g} \mathrm{mL}-1$ & [85] \\
\hline & Virucidal & - & 1 & - & - & - \\
\hline
\end{tabular}

EDXRF: Energy-dispersive X-ray spectroscopy; TEM: transmission electron microscopy; FTIR: Fourier transform infrared; XRD: X-ray diffraction; UV-Vis: UV-Vis spectroscopy; AFM; Atomic Force Microscopy; SEM: scanning electron microscopy; DLS: Dynamic light scattering; FESEM: Field emission scanning electron microscopy; GPS: gel permeation chromatography; QMS: quadrupole mass spectroscopy; VSM: vibrating-sample magnetometer.

As described above, there are a large number of biological resources for the synthesis of NPs and their physical-chemical properties depend on many factors. Consequently, analytical techniques should be applied for the characterization of NPs [86]. In general, some techniques such as UV-Vis spectroscopy, X-ray diffraction, Fourier transform infrared, energy dispersive $\mathrm{X}$-ray spectroscopy, scanning electron microscopy, transmission electron microscopy, and dynamic light scattering have been widely used by researchers [87] (Table 1). For example, UV-Vis spectroscopy allows the optical properties to be determined, while X-ray diffraction provides information about the crystalline structure of the NPs and, consequently, the chemical composition of the obtained NP [88]. Otherwise, energy dispersive X-ray spectroscopy examines the elemental composition, and Fourier transform infrared provides information about the surface composition and ligand binding, which is an important technique not only regarding the chemical properties of the NPs, but also for investigating the capping composition. In addition, microscopic techniques provide morphological characterizations such as shape, size, aggregation state, and surface properties. Finally, the dynamic light scattering technique is widely used to determine the hydrodynamic size, homogeneity, surface charge, and stability over time of NPs in suspension, allowing the characterization under different conditions of temperature and $\mathrm{pH}$, among others to be determined [89].

\section{Bactericidal and Virucidal Activities of Biogenic Metal-Based NPs}

The antimicrobial actions of metal-based NPs are based on the release of metal ions, cell membrane damage, DNA interaction/damage, and free radical generation. Further 
discussions on the mechanisms of the toxicity of NPs can be found elsewhere [2,27]. This section discusses selected examples of recent papers based on the antimicrobial activity of different metal-based NPs synthesized by biogenic routes.

\subsection{Bactericidal and Virucidal Activities of AgNPs}

Biogenic AgNPs are interesting eco-friendly tools that can combat pathogenic bacteria and viruses, including multi drug-resistant bacteria, which have appeared due to the overuse of antibiotics against infectious diseases, or the overuse of pesticides against pest plants. AgNPs synthesized using cyanobacterium Leptolyngbya sp. WUC 59 cell-free extract suppressed the growth of Bacillus subtilis and Escherichia coli bacteria, at $10 \mathrm{mg} \mathrm{L}^{-1}$ and with a minimum inhibitory concentration (MIC) of $8 \mathrm{mg} \mathrm{L}^{-1}$ [39]. Antibacterial assays with AgNPs synthesized by using Calligonum comosum roots and Azadirachta indica leaf extracts were effective against Pseudomonas aeruginosa, Escherichia coli, and Staphylococcus aureus at concentrations that ranged between 10.9 and $21.4 \mathrm{mg} \mathrm{L}^{-1}$ [61]. A double-green approach for the biosynthesis of AgNPs has been proposed by the authors of [90]. AgNPs were biosynthesized using chitosan as a reducing agent, which was obtained from the carapace of marine crabs Portunus pelagicus and combined with the microwave technique. The AgNPs obtained ranged between 7 and $25 \mathrm{~nm}$ in size, with near-spherical shapes, and showed an efficient antimicrobial activity against Edwardsiella tarda and Escherichia coli. AgNPs derived from Albizia lebbeck Bark extract (average size of $27 \mathrm{~nm}$ ) showed antimicrobial activity against multi-drug resistant bacteria P. aeruginosa and S. marcescens. The proposed antibacterial activity was assigned to the efficient penetrability of the NPs on the bacterial cell membrane. Indeed, the cell damage was confirmed by demonstrating the significant alterations in the cellular architecture, as assayed by scanning electron microscopy [91]. In a similar work, AgNPs (30 mg) synthesized by using Allium sativum clove extract were effective against Klebsiella pneumoniae, Pseudomonas aeruginosa, Serratia marcescens, Streptococcus pyogenes, and Staphylococcus aureus [62]. Interestingly, this work not only demonstrated the antimicrobial capacity of freshly prepared AgNPs, but also demonstrated that the antimicrobial capacity of NPs was maintained after AgNPs were stored at $4{ }^{\circ} \mathrm{C}, 22^{\circ} \mathrm{C}$, and $37^{\circ} \mathrm{C}$ or even at thermal treatment at $300^{\circ} \mathrm{C}, 500{ }^{\circ} \mathrm{C}$, for $1 \mathrm{~h}$.

The difficulties related to the treatment of bacterial infection in the urinary tract due to the inaccessibility of traditional antibiotics to reach urinary tract infections caused by the uropathogenic Escherichia coli, which causes biofilm formation, were efficiently overcome by using AgNPs biogenically synthesized with a fungal extract from Fusarium scirpi [60]. AgNPs showed a MIC of $25 \mathrm{mg} \mathrm{mL}^{-1}$ over planktonic bacteria, but a sub-MIC concentration of only $7.5 \mathrm{mg} \mathrm{L}^{-1}$ was needed to cause a $97 \%$ inhibition in the formation of the biofilm or to produce $80 \%$ of the mature bacterial biofilm. An innovative strategy against biofilm-forming multidrug resistant bacteria was proposed by the authors of [92]. The authors biosynthesized small AgNPs (13.47 $\pm 12 \mathrm{~nm}$ ) using the supernatants of Bacillus horikoshii AJM-A1 and conjugated them with the alpha-amylase enzyme from Bacillus subtilis. Conjugated AgNPs were evaluated on multidrug-resistant strains Klebsiella pneumoniae and methicillin-resistant Staphylococcus aureus (MRSA). The results demonstrated that conjugated AgNPs at concentrations that ranged between $200 \mu \mathrm{g} \mathrm{mL} L^{-1}$ and $800 \mu \mathrm{g} / \mathrm{mL}^{-1}$ caused a biofilm reduction between 80 and $95 \%$, approximately, and were more effective than non-conjugated AgNPs or alpha-amylase independently [92]. Similarly, AgNPs (48-67 nm diameters) synthesized from leaf extracts of Catharanthus roseus and Azadirachta indica inhibited the growth of E. coli, K. pneumoniae, S. aureus, and P. aeruginosa isolated from patients with septic wound infections [93]. However, P. aeruginosa was inhibited by higher concentrations of AgNPs $\left(80 \mu \mathrm{g} \mu \mathrm{L}^{-1}\right)$, compared to E. coli, K. pneumoniae and S. aureus that were inhibited at $10 \mu \mathrm{g} \mu \mathrm{L}^{-1}$ of AgNPs.

Interestingly, AgNPs can also act as agents to recover the antimicrobial activity of antibiotics on resistant bacteria. In this sense, AgNPs synthesized by using a Rosa damascenes extract and conjugated with cefotaxime were efficient against cefotaxime-resistant $E$. coli strains. Conjugated AgNPs $(8.48-25.3 \mathrm{~nm}$ ) showed a higher antimicrobial activity against 
resistant bacteria, compared to non-conjugated AgNPs or pure antibiotics, restoring the efficiency of the cefotaxime [94].

Moreover, AgNPs have also been loaded onto graphene oxide (GO) nanomaterials. AgNPs synthesized by a coffee extract (average size of $70 \mathrm{~nm}$ ) were incorporated on GO sheets. The nanocomposite showed bactericidal activity on Staphylococcus aureus due to the release silver ions, as well as photobactericidal effects due to photocatalytic activity induced by the blue light-irradiation [95]. Since AgNPs and regenerated silk fibroin have shown potential applications in preventing wound related infections, a photo-assisted green synthesis of silver doped silk fibroin/carboxymethyl cellulose nanocomposite hydrogels has been reported [96]. Silk fibroin was obtained from raw Bombyx mori cocoons, and tyrosine residues on silk fibroin served as the reductant agent of silver ions, which were exposed to UV radiation to complete the green synthesis of AgNPs. The nanoparticles in the composite hydrogels presented a diameter mean value of $92 \mathrm{~nm}$ and demonstrated a strong and consistent antimicrobial activity against $E$. coli, S. aureus S. epidermidis, MRSA, and $P$. aeruginosa. The authors suggested that this composite can potentially be used as a wound dressing with antimicrobial and regenerative properties [96]. However, further studies are required.

Recent important works have also shown thev antimicrobial activity of biogenic synthesized AgNPs on pathogenic plant bacteria. In this regard, AgNPs $(12 \mathrm{~nm})$ biosynthesized by the mycelial aqueous extract of agriculturally beneficial fungi Pythium oligandrum were effective against Clavibacter michiganensis subsp. michiganensis $(\mathrm{Cmm})$ known for producing bacterial canker in tomatoes [59]. In a similar strategy, AgNPs (8-28 nm in size) were biosynthesized by using Moringa oleifera leaves, which act as the main reducing and stabilizing agent [97]. The obtained NPs were applied on Citrus reticulata inoculated with Xanthomonas axonopodis pv. Citri. The results demonstrated that $30 \mathrm{ppm}$ of AgNPs was a suitable concentration for creating a resistance against canker disease, produced by $X$. axonopodis pv. Citri [97]. Moreover, biogenic AgNPs (25 to $50 \mathrm{~nm}$ in size) synthesized by using the endophytic bacterium Bacillus siamensis strain C1 effectively inhibited the rice pathogenic bacteria Xanthomonas oryzae pv. oryzae strain LND0005 and Acidovorax oryzae strain RS, at an NP concentration of $20 \mathrm{mg} \mathrm{mL}^{-1}$ [98].

Although some progress has been achieved by from using biogenic synthesized AgNPs as antibacterial agents, the antiviral activity of these NPs has been studied less compared with the AgNPs that have been synthesized by traditional routes (chemical and/or physical methods). However, some important works have described the ability of biogenic AgNPs against pathogenic viruses. For instance, blue-green algae Oscillatoria sp produced spherical AgNPs (15-50 nm in size) with toxic effects against the Herpes Simplex (HSV-1) virus, causing a 90\% reduction in its cytopathic effect [30]. In a similar approach, AgNPs produced by the seaweed Sargassum wightii algae demonstrated antiviral activity against the Herpes Simplex Virus (HSV-1 and HSV-2) [99].

Interestingly, AgNPs (5-15 nm in size) obtained from an aqueous extract from Panax ginseng roots assisted by the ultra-sonication method were effective against the influenza A virus (strain A/PR/8) (Sreekanth et al., 2018). A Red Sea Sponge (Amphimedon) was employed in the biosynthesis of AgNPs (8-14 nm in size), assisted by silico modeling and metabolic profiling [100]. The NPs displayed protease and helicase inhibition activity against the hepatitis $\mathrm{C}$ virus (HCV), due to the presence of bio-compounds with anti$\mathrm{HCV}$ activity in Amphimedon [94]. Other viruses such as the chikungunya virus, white spot syndrome virus, and dengue virus have also been effectively treated with biogenic AgNPs $[17,101,102]$. Further studies are required on this topic.

\subsection{Bactericidal and Virucidal Activities of $\mathrm{CuNPs}$ and Copper Oxides $\mathrm{CuO-NPs}$}

Spherical CuNPs $(2-10 \mathrm{~nm}$ ) were prepared by using an aqueous extract from Vaccinium myrtillus L. (bilberry) and Vaccinium uliginosum L. subsp. Gaultherioides (false bilberry) and demonstrated high and broad antimicrobial activity against both Gram-negative and Grampositive bacteria. Biosynthesized CuNPs reduced colony-forming units (CFU) $\mathrm{mL}^{-1}>3$ in 
S. aureus, E. coli and S. cerevisiae, after 1 to $3 \mathrm{~h}$ of incubation [103]. CuNPs synthesized using a Manilkara zapota leaf extract resulted in spherical NPs with an average size of between 19 and $42 \mathrm{~nm}$, and exhibited antibacterial activity against E. coli, B. subtilis, S. aureus, V. harveyi, and $V$. parahaemolyticus bacterial strains [104]. In a further work, CuNPs were synthesized by using a Hagenia abyssinica (Brace) JF. Gmel. leaf extract. This process led to the formation of a mixture of spherical, hexagonal, triangular, cylindrical, and irregular CuNPs with an average particle size of $35 \mathrm{~nm}$. These NPs (at $1 \mathrm{mg} \mathrm{mL}^{-1}$ ) showed antimicrobial activity on S. aureus, Bacillus subtilis, E. coli, and P. aeruginosa [70]. The leaf extract of Syzygium cumini favors the synthesis of spherical CuNPs $(28-35 \mathrm{~nm})$ and was shown to form excellent antimicrobial compounds against methicillin- and vancomycin-resistance S. aureus [105]. The Cissus vitiginea leaf extract proved to be a suitable strategy for the synthesis of spherical shape CuNPs (5-20 nm in size). The NPs were efficient as antimicrobial agents against several urinary tract infection pathogens such as E. coli, Enterococcus sp., Proteus sp., and Klebsiella $s p$ [69]. In an interesting recent work, CuNPs were generated in situ on hybrid cellulose nanocomposite films and loaded with tamarind nut powder as reinforcing fillers [106]. The use of pectin from citrus peel as a stabilizer agent, citric acid as a reducing agent, and microwave irradiation were proposed as a green and efficient tool in the biosynthesis of CuNPs [107]. Synthesized NPs $(40.9 \pm 13.6 \mathrm{~nm})$ with irregular polygon shapes showed high antimicrobial activities against $E$. coli and $S$. aureus. Interestingly, plants with a historical capacity for use in cutaneous wound healing, such as Allium eriophyllum Boiss, have been used in the synthesis of CuNPs to evaluate their antimicrobial potential. There is also the possibility to use these NPs in cutaneous wound healing [108]. The authors reported the effective formation of small CuNPs $(25-35 \mathrm{~nm})$ using an Allium eriophyllum Boiss leaf aqueous extract, and potent antimicrobial activity $\left(>4 \mathrm{mg} \mathrm{L}^{-1}\right)$ against $P$. aeruginosa, S. aureus, B. subtilis, S. pneumonia, E. coli, and S. typhimurium. Moreover, ointment application containing CuNPs raised the wound contracture, hydroxyl proline, vessel, hexosamine, hexuronic acid, fibrocyte and fibrocytes/fibroblast rate, and significantly decreased the wound area, total cells, neutrophils, and lymphocytes, accelerating tissue repair [108]. The Cardiospermum halicacabum leaf extract produced CuNPs (30-40 $\mathrm{nm}$ in size), which demonstrated antibacterial activity against $P$. aeruginosa and S. aureus, with a high susceptibility at an NP concentration of $50 \mu \mathrm{g} \mathrm{mL} \mathrm{L}^{-1}$. Moreover, anti-biofilm capacity was also demonstrated, since $100 \mu \mathrm{g} \mathrm{mL} \mathrm{L}^{-1}$ of CuNPs inhibited $79 \%, 72 \%$, and $78 \%$ of $P$. aeruginosa, S. aureus, and E. coli biofilm formation, respectively [109]. The incubation of $\mathrm{CuO}-\mathrm{NPs}\left(15-25 \mathrm{~nm}\right.$ in size at $\left.100 \mu \mathrm{g} \mathrm{mL}^{-1}\right)$ synthesized from the Camellia japonica plant leaf extract decreased the viability of the uropathogens P. aeruginosa and K. pneumoniae, in addition to the promotion of cell membrane damage [110]. As can be observed, most of the studies reported the antibacterial activity of biogenic CuNPs, and more studies based on biogenic $\mathrm{CuO}$ NPs should be further investigated.

Regarding the antiviral effects of CuNPs and CuO-NPs, more studies are welcome since most of the studies have focused on chemically synthesized NPs and scarce information in the literature is related to biogenic NPs [111]. The fruit extract of Syzygium alternifolium (Wt.) Walp. was used in the biosynthesis of spherical CuO-NPs $(2-70 \mathrm{~nm}$ in size) with a negative zeta potential $(-49 \mathrm{mV})$. These NPs demonstrated antiviral activity against the Newcastle Disease Virus (NDV). In ovo assays showed that an egg treated with CuO-NPs (at $25 \mu \mathrm{g} \mathrm{mL}^{-1}$ ) led to embryo deaths at 24, 48, and $96 \mathrm{~h}$ of incubation [73].

\subsection{Bactericidal and Virucidal Activities of $\mathrm{ZnO}-\mathrm{NPs}$}

ZnO-NPs have attracted special attention due to their low cost, photochemical stability, and photocatalytic activity. This last property has also conferred to ZnO-NPs antimicrobial capacities due to the possibility to generate reactive oxygen species (ROS), such as superoxide anion $\left(\bullet \mathrm{O}_{2}{ }^{-}\right)$, hydroxyl radical $(\bullet \mathrm{OH})$, and hydrogen peroxide $\left(\mathrm{H}_{2} \mathrm{O}_{2}\right)$, upon NP exposition to UV irradiation [112]. Moreover, $\mathrm{ZnO}-\mathrm{NPs}$ can produce antimicrobial activity by their direct interaction with microorganisms upon the release of $\mathrm{Zn}^{2+}$ ions, without the need for UV light exposure [113]. Interesting, the photocatalytic performance of $\mathrm{ZnO}$ 
nanostructures under visible light irradiation can be promoted and enhanced by doping these NPs with transition and noble metals [106]. Detailed information about several synthetic routes, photocatalytic activity, and details about the most used dopants (metal and non-metals) were extensively reviewed by the authors of [112].

Eucalyptus globulus essential oil was used to synthesize $\mathrm{ZnO}-\mathrm{NPs}(24 \mathrm{~nm})$, which showed efficient antibacterial activity at a concentration of $100 \mu \mathrm{g} \mathrm{mL}^{-1}$ against K. pneumoniae [114]. NPs showed an important anti-biofilm formation with biofilm inhibition of $85 \%$ and $97 \%$ against S. aureus ATCC 25923 and P. aeruginosa ATCC 27853, respectively. Similar results were obtained with hexagonal $\mathrm{ZnO}-\mathrm{NPs}(50-100 \mathrm{~nm})$ synthesized using the alcohol-free Artemisia pallens plant extract as a reducing agent [115]. The zone inhibition method was carried out to evaluate the antimicrobial activity demonstrating that the zone inhibition against B. subtilis, S. aureus, and E. coli was $12 \mathrm{~mm}, 7 \mathrm{~mm}$, and $6 \mathrm{~mm}$, respectively. Moreover, the determined MIC values were $31.25 \mu \mathrm{g} \mathrm{mL} \mathrm{L}^{-1}$ for $S$. aureus and $62.5 \mu \mathrm{g} \mathrm{mL}^{-1}$ for B. subtilis and E. coli. Multi-drug-resistant bacteria isolated from patients in nursing care such as Acinetobacter baumannii was efficiently treated with ZnO-NPs (18 $\mathrm{nm}$ ) synthetized by the Caryophyllus aromaticus leaf extract and showed a MIC value of $0.19 \mu \mathrm{g} \mathrm{mL}{ }^{-1}$ [116]. Moreover, anti-biofilm activity was assessed against the multi-drugresistant A. baumannii as well as five clinical strains of $A$. baumannii ATCC 19606 . The results demonstrated that only $1 / 8$ of the MIC value $\left(0.012 \mu \mathrm{g} \mathrm{mL}^{-1}\right)$ of ZnO-NPs was efficient to reduce the biofilm production. Moreover, at $1 / 2$ of the MIC $\left(0.045 \mu \mathrm{g} \mathrm{mL}^{-1}\right)$ and $1 / 4$ of the MIC $\left(0.023 \mu \mathrm{g} \mathrm{mL}^{-1}\right)$ biofilm formation was considerably reduced in the six-strains evaluated [116]. In other works, $\mathrm{ZnO}-\mathrm{NPs}(15-20 \mathrm{~nm})$, synthesized using the leaf extract of Coleus amboinicus, demonstrated effective antimicrobial activity against Salmonella typhi (B-4420), Klebsiella pneumoniae (ATCC-27738), Escherichia coli (O157: H7), Staphylococcus aureus (6538 P), and Bacillus cereus (ATCC 7064). In addition, these NPs were used for the antimicrobial treatment of burn wound infections, accelerating wound closure rate [117].

Nanoflowers are newly developed 3-D nanostructures that have shown high stability and important biomedical applications [118]. In this regard, the biosynthesis of $\mathrm{ZnO}$ nanoflowers was effective by using the Withania coagulans extract as a reducing agent [119]. Nanoparticles with a size range of 360-550 $\mathrm{nm}$ and with a Wurtzite hexagonal structure were formed. Antimicrobial activity was obtained with 5, 10, and $20 \mu \mathrm{g} \mathrm{mL}^{-1}$ of $\mathrm{ZnO}$ nanoflowers against $S$. aureus and P. aeruginosa, which was attributed to the induced oxidative stress produced by $\mathrm{ZnO}$ nanoflowers and by the enhanced surface area to volume ration of the protruding projections as asteroideal nano-petals.

As a strategy to enhance the antimicrobial activity of $\mathrm{ZnO}-\mathrm{NPs}$, these NPs have been doped with several compounds, forming nanocomposites, nanoneedles, and hybrid NPs, among others. However, this strategy has been applied only with ZnO-NPs synthesized by chemical routes (Li et al. 2020b) and should be extended to biogenic synthesized NPs [112]. Interestingly, the preparation of nanoneedles composed by chitosan and $\mathrm{Zn}$ doped with bismuth oxide (CS/ $\mathrm{Zn}_{0.75} \mathrm{Bi}_{2} \mathrm{O}_{3}$ nanoneedle) has been reported [120]. The nanoneedle showed inhibitory effects against $S$. aureus and E. coli with inhibition zones of 32 and $35 \mathrm{~mm}$, respectively. Sericin, a natural protein produced by the silkworm, Bombyx mori, was used to biosynthesize $\mathrm{Ag} / \mathrm{ZnO}$ hybrid NPs on a sericin/agarose composite film [121]. The composite was characterized by its high hydrophilicity and water absorption ability, as well as its favorable mechanical properties. Moreover, the composite showed strong antimicrobial activity against $S$. aureus and E. coli, where the disruption of the bacterial cell wall integrity was observed, due to the synergistic effect of AgNPs and ZnO-NPs [121]. Recently, the preparation of curcumin-loaded $\mathrm{ZnO}-\mathrm{NPs}\left(73 \mathrm{~nm}\right.$ in size and $654 \mathrm{~m}^{2} \mathrm{~g}^{-1}$ ) decorated with mesoporous silica as a tissue adhesive, has been reported [116]. The results found in animal studies showed a significant antimicrobial activity of the nanomaterial as well as its effectivity for gluing wounds in less than one minute and healing within five days [122]. Zinc oxide-xanthan gum nanocomposite, formed by a green route, at a concentration of $128 \mu \mathrm{g} \mathrm{mL}{ }^{-1}$ showed a high capacity to reduce quorum sensing related to 
virulence factors, such as chitinase $70 \%$ and violacein $(61 \%)$ in Chromobacterium violaceum and protease (72\%), and prodigiosin $(71 \%)$ in Serratia marcescens [123].

$\mathrm{ZnO}-\mathrm{NPs}$ have also been applied to control pathogenic plant bacteria. In this sense, ZnO-NPs synthesized by using the Thymbra spicata var. spicata L. (TS) plant extract showed a hexagonal nanorod-like structure between $426 \mathrm{~nm}$ and $540 \mathrm{~nm}$ in diameter and antimicrobial activity against several plant pathogenic bacteria such as $P$. syringae pv. Phaseolicola (PspE22), P. carotovorum subsp. Carotovorum (PccSy17), C. michiganensis subsp. Michiganensis (CmmAd12), and P. cichori (PcSa2) [124]. Interestingly, the authors reported that pristine $\mathrm{ZnO}-\mathrm{NPs}$ were less effective than biosynthesized ZnO-NPs. Finally, many works have reported virucidal activity by $\mathrm{ZnO}-\mathrm{NPs}$. Indeed, the antiviral capacity of $\mathrm{ZnO}-$ NPs against HSV-1 and HSV-2, human rhinovirus (HRV), and human immunodeficiency viruses (HIV), has been already reviewed [125]. However, all the works were developed with chemically synthesized NPs. To the best of our knowledge, biogenic synthesized $\mathrm{ZnO}-\mathrm{NPs}$ have not been tested against pathogenic viruses. Considering the advantages of biogenic routes and the reported antibacterial actions of these NPs, further studies that aim to treat human and plant viruses with biogenic synthesized $\mathrm{ZnO}-\mathrm{NPs}$ are welcome.

\subsection{Bactericidal and Virucidal Activities of $\mathrm{TiO}_{2}-\mathrm{NPS}$}

The antimicrobial effect of biogenic $\mathrm{TiO}_{2}-\mathrm{NPs}$ synthesized with an extract of Vitex negundo Linn with or without the addition of ionic liquid (1-ethyl-3-methylimidazolium tetrafluoroborate-[EMIM]+BF4-) against S. aureus and E. coli has been reported [126]. The ionic liquid was designed to act as a self-assembling template agent during the synthesis of $\mathrm{TiO}_{2}-\mathrm{NPs}$. Microscopy revealed that both NPs presented a rod-shape and spherical morphologies (size in the range of 15-26 nm). The results demonstrated an important growth inhibition of both S. aureus and E. coli as assayed by agar diffusion assays [126]. Similarly, the leaf extract of Morinda citrifolia was used to prepare quasi-spherical $\mathrm{TiO}_{2}-\mathrm{NPs}$ (15-19 $\mathrm{nm}$ in size), which demonstrated antibacterial activity at an NP concentration from 50 to $150 \mu \mathrm{g} \mathrm{mL}{ }^{-1}$ against S. aureus, E. coli, B. subtilis, and P. aeruginosa, in a dose-response manner [127]. In addition, spherically-shaped $\mathrm{TiO}_{2}-\mathrm{NPs}$ synthesized with the aqueous leaf extract of Trigonella foenum-graecum showed an important activity against $E$. faecalis, $S$. aureus, S. faecalis, B. subtilis, Yersinia enterocolitica, E. coli, P. aeruginosa, K. pneumoniae, and C. albicans [128]. Furthermore, triangular $\mathrm{TiO}_{2}-\mathrm{NPs}(20-50 \mathrm{~nm}$ in size) synthesized with orange peel extract have antimicrobial activity against S. aureus, E. coli, and P. aeruginosa at doses from 6.75 to $50 \mathrm{mg} \mathrm{mL}^{-1}$ [129]. In addition, spherical $\mathrm{TiO}_{2}-\mathrm{NPs}$ (average size of $69 \mathrm{~nm}$ ) synthesized from the root extract of Glycyrrhiza glabra, from 0.62 to $5 \mu \mathrm{g} \mathrm{mL} \mathrm{L}^{-1}$, have a good toxic effect against K. pneumoniae and S. aureus [130]. $\mathrm{TiO}_{2}-\mathrm{NPs}$ (spherical shape and size from 15 to $50 \mathrm{~nm}$ ) produced by the Azadirachta indica leaf extract had a strong antibacterial activity against E. coli, B. subtilis, Salmonella typhi, and K. pneumonia, where the antimicrobial effect of the NP was higher compared to bulk $\mathrm{TiO}_{2}$. The results indicated that the lowest MIC value was $10.42 \mu \mathrm{g} \mathrm{mL}^{-1}$ for the NPs against S. typhi and E. coli, while the lowest $\mathrm{MBC}$ value was $83.3 \mu \mathrm{g} \mathrm{mL} \mathrm{m}^{-1}$ for the NPs against $\mathrm{K}$. pneumonia. Recently, an extract from the Mentha arvensis leaves was used to synthesize spherical $\mathrm{TiO}_{2}-\mathrm{NPs}$ (20-70 nm), which demonstrated antibacterial effects against Proteus vulgaris at doses from 10 to $30 \mathrm{mg} \mathrm{mL}^{-1}$, in a dose-response manner. Interesting, the same NPs at the same dose had no effect towards E. coli or S. aureus [131]. These results indicate that the antimicrobial activity of biogenic $\mathrm{TiO}_{2}-\mathrm{NPs}$ may vary based on the bacteria strain. Moreover, $\mathrm{TiO}_{2}-\mathrm{NPs}$ (50-90 nm in size with spherical and square shapes), synthesized from the root extract of Withania somnifera demonstrated antibacterial effects against E. coli, P. aeruginosa, S. aureus, Listeria monocytogenes, and Serratia marcescens through the inhibition of biofilms and enhanced the formation of ROS [132].

Taken together, important papers have described the successful preparation of biogenic $\mathrm{TiO}_{2}-\mathrm{NPs}$, mainly by a plant-mediated synthesis, leading to the formation of particles at the nanoscale with different morphologies and potent antimicrobial activity. However, 
biogenic synthesized $\mathrm{TiO}_{2}-\mathrm{NPs}$ have not been used as antiviral agents, and studies on this topic are welcome.

\subsection{Bactericidal and Virucidal Activities of FeO-NPS}

Iron-based nanoparticles ( $\mathrm{FeO}-\mathrm{NPs})$, such as magnetite $\left(\mathrm{Fe}_{3} \mathrm{O}_{4}\right)$, hematite $\left(\mathrm{Fe}_{2} \mathrm{O}_{3}\right)$, and maghemite $\left(\gamma-\mathrm{Fe}_{2} \mathrm{O}_{3}\right)$ NPs have been extensively used in different areas including biomedical applications due to their superparamagnetic properties at room temperature [133]. These NPs are different phases of iron oxide with similar crystallographic structures [134]. Recently, in addition to chemical and physical routes, biogenic methods have been used to prepare superparamagnetic FeO-NPs $[135,136]$. The main biomedical applications of FeO-NPs are in cancer diagnoses and treatment, however, more recently these NPs have been explored as antimicrobial agents, as described below.

$\alpha-\mathrm{Fe}_{2} \mathrm{O}_{3}-\mathrm{NPs}$ (average size of $16 \mathrm{~nm}$ ) with asymmetric morphology and uniform dispersion, were obtained from the Sida cordifolia plant extract, which is rich in carbohydrates, alkaloids, proteins, glycosides, tannins, terpenoid, and flavonoids [137]. The proposed mechanism of NP formation involves the formation of an octahedral aqua complex of $\mathrm{Fe}$ (III), which undergoes a decomposition into $\mathrm{Fe}(\mathrm{OH})^{2+}$ that can form a complex with functional groups of phytochemicals derived from the plant extract. By increasing the temperature, NPs of $\alpha-\mathrm{Fe}_{2} \mathrm{O}_{3}$ are formed from $\mathrm{Fe}(\mathrm{OH})^{2+}$ species. The antibacterial activity of $\alpha-\mathrm{Fe}_{2} \mathrm{O}_{3}-\mathrm{NPs}$ (at $50 \mu \mathrm{g} \mathrm{mL} \mathrm{mL}^{-1}$ ) was evaluated against different Gram-positive and Gram-negative bacteria (B. subtilis, S. aureus, E. coli, and K. pneumonia), and compared with traditional antibiotics (at $50 \mu \mathrm{g} \mathrm{mL}{ }^{-1}$ ). It was observed that $\alpha-\mathrm{Fe}_{2} \mathrm{O}_{3}-\mathrm{NPs}$ were efficient in the combating of Gram-positive bacteria such as B. subtilis, demonstrating the good antibacterial action of $\alpha-\mathrm{Fe}_{2} \mathrm{O}_{3}-\mathrm{NPs}$ compared to the commercial antibiotic neomycin. Moreover, the authors have explained that these NPs are stable in the environment and have a lesser contribution in the release of metal ions for antibacterial action. However, UV light activates reactive oxygen species, leading to the desorption of the bacterial membrane, resulting in death [137]. Interestingly, the flower extract from Nyctanthes arbor tristis, popularly known as the "Sad Tree", has been used to synthesize $\mathrm{Fe}_{2} \mathrm{O}_{3}-\mathrm{NPs}$ [138]. Field emission scanning electron micrograph (FE-SEM) images demonstrated NPs with grains from 50 to $180 \mathrm{~nm}$, indicating the formation of clusters with spherical morphology. The obtained NPs demonstrated antimicrobial activity against K. pneumoniae and S. aureus, at a concentration of $100 \mu \mathrm{g} \mathrm{mL}^{-1}$. The NPs were found to be more efficient against the Gram-positive bacteria S. aureus compared to the Gram-negative K. pneumoniae [138].

Eucalyptus robusta leaf extracts (in the proportion of 1:1, 2:1, and 1:2 in relation to the iron salt) were used to synthesize iron NPs (Fe-NPs) [139]. The obtained NPs have a spherical morphology with average size of $8 \mathrm{~nm}$, at a solid state, along with the presence of some clusters with a width of $70 \mathrm{~nm}$, leading to the formation of some degree of aggregates. These NPs synthesized under the different conditions were tested against $P$. aeruginosa, $B$. subtilis, E. coli, and S. aureus. The antibacterial action of the Fe-NPs was compared to the activity of the Eucalyptus robusta leaf extracts, since the phytochemicals derived from this extract are known to have antimicrobial activity. The authors demonstrated the significant antimicrobial action of Fe-NPs against the Gram-positive B. subtilis, indicated by the accumulation of Fe-NPs in the cytoplasmic region of the microorganism, which might lead to membrane rupture leading to the death of the microorganism. In addition, the possible mechanism of the antimicrobial activity of Fe-NPs is assigned to the generation of ROS leading to cellular oxidation and cell death. Fe-NPs demonstrated a higher antimicrobial action compared with the pure E. robusta extract. Moreover, the antioxidant effects of the NP were demonstrated [139].

In another study, spherical $\alpha-\mathrm{Fe}_{2} \mathrm{O}_{3}-\mathrm{NPs}$ (average size of $100 \mathrm{~nm}$ ) were obtained from Plectranthus amboinicus (Mint) [140]. Scanning electron microscopy showed the absence of aggregates, which was associated with the capping of the NPs with phytochemicals derived from the plant extract. The antimicrobial activity of the NPs was demonstrated against Klebsiella, Salmonella Typhi, E. coli, and S. aureus [140]. 
In addition to their antimicrobial effect against planktonic bacteria, FeO-NPs also have toxic effects against bacterial biofilms, including the prevention of biofilm formation [141]. Due to their superparamagnetic behavior, the application of an external magnetic field can conduct FeO-NPs allowing their permeation into bacterial biofilms [142]. This is an interesting application of superparamagnetic FeO-NPs that should be further explored.

As for the virucidal actions of Fe-ONPs, recently the anti-virus activity of FeO-NPs synthesized by chemical routes has been demonstrated [143]. New investigations based on the anti-virus actions of biogenically synthesized FeO-NPs are needed. Taken together, important recent publications have described the successful preparation of $\mathrm{FeO}-\mathrm{NPs}$ by biogenic synthesis mediated by plant leaf extracts leading to materials at the nanoscale with potent antimicrobial actions against different bacteria strains. Further studies are required in relation to the anti-virus action of these NPs.

\subsection{Other Biogenic Synthesized Metal-Based NPs (NiO-NPs, Pd-NPs and $\mathrm{SnO}_{2}-\mathrm{NPs}$ )}

Other biogenic metal-based NPs have been explored in relation to different biomedical applications, including antimicrobial activity. For instance, the antibacterial effect of nickel oxide NPs (NiO-NPs) synthesized from the stevia leaf extract has been demonstrated against B. subtilis, S. pneumonia, and E. coli [144]. NiO-NPs were prepared with a broth that originated from the stevia leaf extract in the presence of nickel acetate, leading to the formation of spherical NPs with sizes between 10 and $40 \mathrm{~nm}$. The authors observed a more effective antimicrobial effect of NiO-NPs against the Gram-negative E. coli, compared to the strains of S. pneumoniae and B. subtilis (Gram-positive). In fact, NiO-NPs showed a concentration-dependent toxicity with $70 \%$ bacteria eliminated at a concentration of $200 \mu \mathrm{g} / \mathrm{mL}$ [144].

Likewise, palladium nanoparticles (Pd-NPs), at sizes between 10 and $100 \mathrm{~nm}$, can have antimicrobial effects due to their interaction with molecules outside or inside the cell surface [145]. In this sense, the Garcinia pedunculata roxb leaf extract was used to synthesize spherical Pd-NPs with an average size of $3 \mathrm{~nm}$ [146]. The antimicrobial activity of Pd-NPs has been demonstrated against the bacterium Cronobacter Sakazakii AMD 04. The MIC and MBC assays showed a significant inhibition in biofilm formation upon treatment with Pd-NPs $(0.26 \mathrm{mM})$. A significant decrease in biofilm formation was found for Pd-NPs at $0.39 \mathrm{mM}$ and $0.52 \mathrm{mM}$ [146].

Similar to NiO-NPs and Pd-NPs, tin NPs $\left(\mathrm{SnO}_{2}-\mathrm{NPs}\right)$ also have antimicrobial activity. Saraca indica flowers were used in the synthesis of spherical $\mathrm{SnO}_{2}-\mathrm{NPs}$ (size from 2.2 to $18 \mathrm{~nm}$ ), and their antimicrobial activity was revealed against E. coli, a Gram-negative bacterium with a thicker cell wall and a more complex protective membrane, indicating that these NPs have the ability to penetrate the outer membrane [147]. The authors assumed that ROS produced through the interaction between $\mathrm{SnO}_{2}-\mathrm{NPs}$ and the bacterial cell membrane allowed the metal NPs to penetrate into the cell [147].

Taken together, these few articles have described the successful preparation of other types of metallic nanoparticles, such as NiO-NPs, Pd-NPs and $\mathrm{SnO}_{2}-\mathrm{NPs}$ by biogenic routes (plant-mediated synthesis) giving rise to NPs with spherical morphologies, small sizes and with antimicrobial actions. Further studies are still welcome in relation to this topic to further explore the antibacterial action of these NPs. Moreover, we did not find biogenic synthesized NPs that were effective against viruses; hence, further studies in this area would produce important contributions.

\section{Conclusions, Challenges and Perspectives}

Nanobiotechnology is the combination of interdisciplinary principles that involve areas of knowledge related to chemistry, physics, biology, and material science, and for many decades it has been providing a purpose to innovative applications mainly in the fields of medicine and biomedicine. The development of metal and metal oxide NPs, including noble metals, such as silver, can be obtained by greener and friendlier routes in comparison to the most well-known chemical and physical syntheses. Green synthesis, also 
known as biogenic synthesis, is one of the most discussed alternatives at the moment for obtaining NPs with medical relevant applications. As stated in this work, biogenic routes are considered less toxic, cleaner, more economically viable and a scalable type of route, compared with traditional methods (chemical and physical routes). A typical biogenic route can use plant extracts, algae, yeasts, fungi, and bacteria. The biological entity acts as a reducing agent, reducing metal ions to the NP, and as a capping agent, avoiding NP aggregation and agglomeration. Overall, the biological mechanism of NP production is based on redox pathways involving the biomolecules of the biological agent and metal ions, which are the NP precursors.

Although much progress has been achieved in the domain of biogenic synthesis of metal-based NPs of medical relevance, there are still some issues to be completely overcome. Not all biological organisms can be successfully used in the biogenic preparation of NPs. For instance, not all algae or bacteria species can be exploited for the synthesis of nanomaterials, since some of them might contain toxic compounds. Moreover, since a great variety of biological entities can be used in the biogenic synthesis of NPs, the mechanism for biogenic synthesis can vary depending on the starting biological material employed, and thus it has not been fully understood. As the chemical redox ability of the biological entity can vary, the obtained nanomaterial can have different chemical and physical features, depending on the starting experimental conditions employed. Thus, a great challenge in the biological synthesis of nanomaterials is the exact control over nanoparticle size distribution, morphology, and chemical surface. In this sense, chemical and physical routes might present a superior ability to control the nanoparticle feature, compared to the biological routes. Further studies are required to better control the reproducibility of the nanomaterial feature in a biogenic synthesis. In fact, the relationship between nanoparticle properties and the experimental biological conditions in a biogenic route of NP needs to be further explored. An important aspect to be further explored in the biogenic synthesis of NPs is the complete characterization of the biological agents responsible for NP production. From the revised literature, more studies aimed at a better characterization of the redox aspects of the biogenic synthesis of NP are still necessary and a complete characterization of the biological agent used in the synthesis is still poorly described. Finally, studies focused on the exploitation of the biogenic production of NPs on an industrial scale are welcome.

Metal based NPs have an important antimicrobial application. Currently, $\mathrm{Cu}, \mathrm{Ag}$, and Fe-based NPs are widely targeted for having bactericidal characteristics and some nanoparticles in particular have virucidal activity, leading to the versatility of their applications against a range of Gram-positive and Gram-negative bacterial strains and some types of viruses. When concluding that over the years some bacteria become resistant to traditional antibiotics, and the increasing problems with multi-resistant bacteria, we face the need to overcome this issue by developing new and versatile antimicrobial agents, such as metal based NPs.

Nanomaterials have the ability to exhibit intrinsic properties such as a large surface area, a reduced size, morphology, and biocompatibility at concentrations able to promote antimicrobial activity. Thus, nanomaterials have unique properties making them suitable candidates to combat a broader spectrum of bacteria and viruses, including resistant biofilms. In this sense, biogenic synthesized metal-based NPs might find important applications in medical, cosmetic, pharmaceutical, agricultural, and food sectors.

Overall, this work has summarized the recent progress in the preparation of biogenic metal-based NPs with important antimicrobial effects. Although progress has been achieved, more research in this topic should be carried out. Most of the antimicrobial effects reported herein are based on antibacterial effects, and there is a lack of studies aimed to evaluate the antivirus effects of these NPs. In addition, a comparison of the efficacy of biogenic NPs with NPs synthesized by chemical and/or physical routes should be further evaluated. Studies focused on the biocompatibility of these NPs, their fate in vivo, including biodistribution and toxicology investigation should be studied. Finally, studies to evaluate the mechanisms of action of these NPs are in high demand. Overall, 
it has been assumed that the small size of the NPs is an important factor that determines their biological activity towards bacteria, viruses, and proteins [148]. We hope that this review brings new inspiration for further research in this active and important topic of medical relevance.

Author Contributions: Writing—-first draft preparation, G.T. and A.B.S.; writing—review and editing, P.F., O.R., J.C.P., P.D., I.M.L. Funding acquisition, G.T., A.B.S. Figures and Tables, G.T. All authors have read and agreed to the published version of the manuscript.

Funding: This research was funded by the ANID-REDES 180003; Dirección de InvestigaciónUniversidad de La Frontera DI21-1004; Project Covid (73-2020)—Universidade Federal do ABC, CONICYT/FAPESP 2018/08194-2 and FONDECYT Projects 1191089 and 1201196.

Conflicts of Interest: The authors declare no conflict of interest.

\section{References}

1. Sánchez-López, E.; Gomes, D.; Esteruelas, G.; Bonilla, L.; Lopez-Machado, A.L.; Galindo, R.; Cano, A.; Espina, M.; Ettcheto, M.; Camins, A.; et al. Metal-Based Nanoparticles as Antimicrobial Agents: An Overview. Nanomaterials 2020, 10, 292. [CrossRef] [PubMed]

2. Tortella, G.R.; Rubilar, O.; Diez, M.C.; Padrão, J.; Zille, A.; Pieretti, J.; Seabra, A.B. Advanced Material Against Human (Including Covid-19) and Plant Viruses: Nanoparticles as a Feasible Strategy. Glob. Chall. 2020, 2000049. [CrossRef]

3. Reverberi, A.P.; Kuznetsov, N.T.; Meshalkin, V.P.; Salermo, M.; Fabiano, B. Systematical analysis of chemical methods in metal nanoparticles synthesis. Theor. Found. Chem. Eng. 2016, 50, 59-66. [CrossRef]

4. Kulkarni, S.K. Synthesis of Nanomaterials-I (Physical Methods). In Nanotechnology: Principles and Practices; Springer: Cham, Switzerland, 2015. [CrossRef]

5. Lee, S.H.; Jun, B.H. Silver Nanoparticles: Synthesis and Application for Nanomedicine. Int. J. Mol. Sci. 2019, 20, 865. [CrossRef]

6. Ziental, D.; Czarczynska-Goslinska, B.; Mlynarczyk, D.T.; Glowacka-Sobotta, A.; Stanisz, B.; Goslinski, T.; Sobotta, L. Titanium Dioxide Nanoparticles: Prospects and Applications in Medicine. Nanomaterials 2020, 10, 387. [CrossRef]

7. Khatoon, U.T.; Mohan Mantravadi, K.; Nageswara Rao, G.V.S. Strategies to synthesise copper oxide nanoparticles and their bio applications-A review. Mat. Sci. Technol. 2018, 34, 1-9. [CrossRef]

8. Wojnarowicz, J.; Chudoba, T.; Lojkowski, W. A Review of microwave synthesis of zinc oxide nanomaterials: Reactants, process parameters and morphoslogies. Nanomaterials 2020, 10, 1086. [CrossRef]

9. Mehravani, B.; Ribeiro, A.I.; Zille, A. Gold nanoparticles synthesis and antimicrobial effect on fibrous materials. Nanomaterials 2021, 11, 1067. [CrossRef]

10. Arias, L.; Pessan, J.; Vieira, A.; Lima, T.; Delbem, A.; Monteiro, D. Iron oxide nanoparticles for biomedical applications: A perspective on synthesis, drugs, antimicrobial activity, and toxicity. Antibiotics 2018, 7, 46. [CrossRef]

11. El Shafey, A.M. Green Synthesis of Metal and Metal Oxide Nanoparticles from Plant Leaf Extracts and Their pplications: A review. Green Process. Synth. 2020, 9, 304-339. [CrossRef]

12. Xu, H.; Wang, L.; Su, H.; Gu, L.; Han, T.; Meng, F.; Liu, C. Making Good Use of Food Wastes: Green Synthesis of Highly Stabilized Silver Nanoparticles From Grape Seed Extract And Their Antimicrobial Activity. Food Biophys. 2015, 10, 12-18. [CrossRef]

13. Tortella, G.; Navas, M.; Parada, M.; Durán, N.; Seabra, A.B.; Hoffmann, N.; Rubilar, O. Synthesis of Silver Nanoparticles Using Extract of Weeds and Optimized by Response Surface Methodology to the Control of Soil Pathogenic Bacteria Ralstonia solanacearum. J. Soil Sci. Plant Nutr. 2019, 19, 148-156. [CrossRef]

14. Ibrahim, E.; Luo, J.; Ahmed, T.; Wu, W.; Yan, C.; Li, B. Biosynthesis of Silver Nanoparticles Using Onion Endophytic Bacterium and Its Antifungal Activity against Rice Pathogen Magnaporthe oryzae. J. Fungi 2020, 6, 294. [CrossRef]

15. Iranmanesh, S.; Shahidi Bonjar, G.H.; Baghizadeh, A. Study of the biosynthesis of gold nanoparticles by using several saprophytic fungi. SN Appl. Sci. 2020, 2, 1851. [CrossRef]

16. Bishoyi, A.K.; Sahoo, C.R.; Sahoo, A.P.; Padhy, R.N. Bio-synthesis of silver nanoparticles with the brackish water blue-green alga Oscillatoria princeps and antibacterial assessment. Appl. Nanosci. 2020, 11, 389-398. [CrossRef]

17. Sharma, V.; Kaushik, S.; Pandit, P.; Dhull, D.; Yadav, J.P.; Kaushik, S. Green synthesis of silver nanoparticles from medicinal plants and evaluation of their antiviral potential against chikungunya virus. Appl. Microbiol. Biotechnol. 2019, 103, 881-891. [CrossRef]

18. Javed, R.; Zia, M.; Naz, S.; Aisida, S.O.; ul Ain, N.; Ao, Q. Role of capping agents in the application of nanoparticles in biomedicine and environmental remediation: Recent trends and future prospects. J. Nanobiotechnol. 2020, 18, 172. [CrossRef]

19. Niska, K.; Knap, N.; Kędzia, A.; Jaskiewicz, M.; Kamysz, K.; Inkielewicz-Stepniak, I. Capping agent-dependent toxicity and antimicrobial activity of silver nanoparticles: An in vitro study. Concerns about potential application in dental practice. Int. J. Med. Sci. 2016, 13, 772-782. [CrossRef]

20. Patil, S.; Chandrasekaran, R. Biogenic nanoparticles: A comprehensive perspective in synthesis, characterization, application and its challenges. J. Genet. Eng. Biotechnol. 2020, 18, 67. [CrossRef] 
21. Yong, D.W.Y.; Lieu, Z.Z.; Cao, X.; Yong, X.E.; Wong, J.Z.L.; Cheong, Y.S.; Brounder, L.; CHIN, W.S. Biogenic synthesis of silver nanoparticles with high antimicrobial and catalytic activities using Sheng Di Huang (Rehmannia glutinosa). Chem. Asian J. 2021. [CrossRef]

22. Durán, N.; Seabra, A.B. Biogenic synthesized Ag/Au nanoparticles: Production, characterization, and applications. Curr. Nanosci. 2018, 14, 1-13. [CrossRef]

23. Chandra, H.; Kumari, P.; Bontempi, E.; Yada, Y. Medicinal plants: Treasure trove for green synthesis of metallic nanoparticles and their biomedical applications. Biocat. Agric. Biotechnol. 2020, 24, 101518. [CrossRef]

24. Giri, V.P.; Pandey, S.; Kumari, M.; Paswan, S.K.; Tripathi, A.; Srivastava, M.; Venketswara Rao, C.; Katiyar, R.; Shekhar Nautiyal, C.; Mishra, A. Biogenic silver nanoparticles as an efficient contrivance for wound healing acceleration than common antiseptic medicine. FEMS Microbiol. Lett. 2019, 366, fnz201. [CrossRef]

25. Niloy, M.S.; Hossain, M.M.; Takikawa, M.; Shakil, M.S.; Polash, S.A.; Mahmud, K.M.; Uddin, F.; Alam, M.; Datta Shubhra, R.; Ali Khan Shawan, M.M.M.; et al. Synthesis of Biogenic Silver Nanoparticles Using Caesalpinia digyna and Investigation of Their Antimicrobial Activity and In Vivo Biocompatibility. ACS Appl. Bio Mater. 2020, 3, 7722-7733. [CrossRef]

26. Singh, P.; Garg, A.; Pandit, S.; Mokkapati, V.R.S.S.; Mijakovic, I. Antimicrobial effects of biogenic nanoparticles. Nanomat 2018, 8 , 1009. [CrossRef]

27. Durán, N.; Durán, M.; Jesus, M.B.; Seabra, A.B.; Favaro, W.J.; Nakazato, G. Silver Nanoparticles: A New View on Mechanistic Aspects on Antimicrobial Activity. Nanomedicine 2016, 12, 789-799. [CrossRef]

28. Jan, H.; Shah, M.; Usman, H.; Khan, M.A.; Zia, M.; Hano, C.; Abbasi, B.H. Biogenic Synthesis and Characterization of Antimicrobial and Antiparasitic Zinc Oxide ( $\mathrm{ZnO}$ ) Nanoparticles Using Aqueous Extracts of the Himalayan Columbine (Aquilegia pubiflora). Front. Mater. 2020, 7. [CrossRef]

29. Gurunathan, S.; Qasim, M.; Choi, Y.; Do, J.T.; Park, C.; Hong, K.; Kim, J.-H.; Song, H. Antiviral Potential of Nanoparticles-Can Nanoparticles Fight Against Coronaviruses? Nanomaterials 2020, 10, 1645. [CrossRef]

30. El-Sheekh, M.M.; Shabaan, M.T.; Hassan, L.; Morsi, H.H. Antiviral activity of algae biosynthesized silver and gold nanoparticles against Herpes Simplex (HSV-1) virus in vitro using cell-line culture technique. Int. J. Environ. Health Res. 2020, 6, 1-12. [CrossRef]

31. Avilala, J.; Golla, N. Antibacterial and antiviral properties of silver nanoparticles synthesized by marine actinomycetes. Int. J. Pharm. Sci. Res. 2019, 10, 1223-1228. [CrossRef]

32. Mehmood, Y.; Farooq, U.; Yousaf, H.; Riaz, H.; Mahmood, R.K.; Nawaz, A.; Abid, Z.; Gondal, M.; Shamshad Malik, N.; Barkat, K. Antiviral activity of green silver nanoparticles produced using aqueous buds extract of Syzygium aromaticum. Pak. J. Pharm. Sci. 2020, 33, 839-845. [PubMed]

33. Haggag, E.; Elshamy, A.; Rabeh, M.; Gabr, N.; Salem, M.; Youssif, K.; Samir, A.; Bin Muhsinah, A.; Alsayari, A.; Ramadan Abdelmohsen, U. Antiviral potential of green synthesized silver nanoparticles of Lampranthus coccineus and Malephora lutea. Int. J. Nanomed. 2019, 14, 6217-6229. [CrossRef] [PubMed]

34. Gogoi, B.; Kumar, R.; Upadhyay, J.; Borah, D. Facile biogenic synthesis of silver nanoparticles (AgNPs) by Citrus grandis (L.) Osbeck fruit extract with excellent antimicrobial potential against plant pathogens. SN Appl. Sci. 2020, 2, 1723. [CrossRef]

35. Nwabor, O.F.; Singh, S.; Ontong, J.C.; Vongkamjan, K.; Voravuthikunchai, S. Valorization of Wastepaper Through Antimicrobial Functionalization with Biogenic Silver Nanoparticles, a Sustainable Packaging Composite. Waste Biomass. Valor. 2020. [CrossRef]

36. Abdelkhalek, A.; Al-Askar, A.A. Green Synthesized ZnO Nanoparticles Mediated by Mentha Spicata Extract Induce Plant Systemic Resistance against Tobacco Mosaic Virus. Appl. Sci. 2020, 10, 5054. [CrossRef]

37. Zhang, D.; Xin-lei, M.; Gu, Y.; Huang, H.; Zhang, G.W. Green synthesis of metallic nanoparticles and their potential applications to treat cancer. Front. Chem. 2020, 8, 799. [CrossRef]

38. Solgi, M.; Taghizadeh, M. Biogenic Synthesis of Metal Nanoparticles by Plants. In Biogenic Nano-Particles and their Use in Agro-Ecosystems; Ghorbanpour, M., Bhargava, P., Varma, A., Choudhary, D., Eds.; Springer: Singapore, 2020. [CrossRef]

39. Singh, A.; Kumar Gautam, P.; Verma, A.; Singh, V.; Shivapriya, P.M.; Shivalkar, S.; KumarSahoo, A.; KumarSamanta, S. Green synthesis of metallic nanoparticles as effective alternatives to treat antibiotics resistant bacterial infections: A review. Biotechnol. Rep. 2020, 25, e00427. [CrossRef]

40. Salem, S.S.; Fouda, A. Green synthesis of metallic nanoparticles and their prospective biotechnological applications: An overview. Biol. Trace Elem. Res. 2021, 199, 344-370. [CrossRef]

41. Ali, M.A.; Ahmed, T.; Wu, W.; Hossain, A.; Hafeez, R.; Islam Masum, M.M.; Wang, Y.; An, Q.; Sun, G.; Li, B. Advancements in plant and microbe-based synthesis of metallic nanoparticles and their antimicrobial activity against plant pathogens. Nanomaterials 2020, 10, 1146. [CrossRef]

42. Durán, N.; Seabra, A.B. Metallic oxide nanoparticles: State of the art in biogenic syntheses and their mechanisms. Appl. Microbiol. Biotechnol. 2012, 95, 275-288. [CrossRef]

43. Khandel, P.; Kumar Yadaw, R.; Kumar Soni, D.; Kanwar, L.; Kumar Shahi, S. Biogenesis of metal nanoparticles and their pharmacological applications: Present status and application prospects. J. Nanostruct. Chem. 2018, 8, 217-254. [CrossRef]

44. Kuppusamy, P.; Yusoff, M.M.; Pragas Maniam, G.; Govindan, N. Biosynthesis of metallic nanoparticles using plant derivatives and their new avenues in pharmacological applications-An updated report. Saudi Pharm. J. 2016, 24, 473-484. [CrossRef]

45. Singh, J.; Dutta, T.; Kim, K.H.; Rawat, M.; Samddar, P.; Kumar, P. Green' synthesis of metals and their oxide nanoparticles: Applications for environmental remediation. J. Nanobiotechnol. 2018, 16, 84. [CrossRef] 
46. Ahmed, S.; Chaudhry, S.A.; Ikram, S. A review on biogenic synthesis of ZnO nanoparticles using plant extracts and microbes: A prospect towards green chemistry. J. Photochem. Photobiol. B 2017, 166, 272-284. [CrossRef]

47. Thakur, B.K.; Kumar, A.; Kumar, D. Green synthesis of titanium dioxide nanoparticles using Azadirachta indica leaf extract and evaluation of their antibacterial activity. S. Afr. J. Bot. 2019, 124, 223-227. [CrossRef]

48. Singh, P.; Kim, Y.J.; Zhang, D.; Yang, D.C. Biological synthesis of nanoparticles from plants and microorganisms. Trends Biotechnol. 2016, 34, 588-599. [CrossRef]

49. Rolim, W.R.; Lamilla, C.; Pieretti, J.C.; Nascimento, M.H.M.; Ferreira, F.F.; Tortella, G.R.; Rubilar, O.; Seabra, A.B. Antibacterial Activity and Cytotoxicity of Silver Chloride/Silver Nanocomposite Synthesized by a Bacterium Isolated from Antarctic Soil. BioNanoSci 2020, 10, 136-148. [CrossRef]

50. Cueva, M.E.; Horsfall, L.E. The contribution of microbially produced nanoparticles to sustainable development goals. Microb. Biotechnol. 2017, 10, 1212-1215. [CrossRef]

51. Grasso, G.; Zane, D.; Dragone, R. Microbial nanotechnology: Challenges and prospects for green biocatalytic synthesis of nanoscale materials for sensoristic and biomedical applications. Nanomaterials 2019, 10, 11. [CrossRef]

52. Qidwai, A.; Pandey, A.; Kumar, R.; Shukla, S.K.; Dikshit, A. Advances in biogenic nanoparticles and the mechanisms of antimicrobial effects. Indian J. Pharm. Sci. 2018, 80, 592-603. [CrossRef]

53. Arya, A.; Gupta, K.; Singh Chundawat, T.; Vaya, D. Biogenic synthesis of copper and silver nanoparticles using green alga Botryococcus braunii and its antimicrobial activity. Bioinorg. Chem. Appl. 2018, 7879403. [CrossRef]

54. Salem, D.M.S.A.; Ismail, M.M.; Aly-Eldeen, M.A. Biogenic synthesis and antimicrobial potency of iron oxide $\left(\mathrm{Fe}_{3} \mathrm{O}_{4}\right)$ nanoparticles using algae harvested from the Mediterranean Sea, Egypt. Egypt. J. Aquat. Res. 2019, 45, 197-204. [CrossRef]

55. Chaudhary, R.; Nawaz, K.; Komal Khan, A.; Hano, C.; Haider Abbasi, B.; Anjum, S. An overview of the algae-mediated biosynthesis of nanoparticles and their biomedical applications. Biomolecules 2020, 10, 1498. [CrossRef]

56. Kashyap, M.; Samadhiya, K.; Ghosh, A.; Anand, V.; Shirage, P.M.; Bala, K. Screening of microalgae for biosynthesis and optimization of $\mathrm{Ag} / \mathrm{AgCl}$ nano hybrids having antibacterial effect. RSC Adv. 2019, 9, 25583. [CrossRef]

57. Roy, A.; Bulut, O.; Some, S.; Mandal, A.K.; Yilmaz, M.D. Green synthesis of silver nanoparticles: Biomolecule-nanoparticle organizations targeting antimicrobial activity. RSC Adv. 2019, 9, 2673-2702. [CrossRef]

58. Ullah, H.; Ullah, Z.; Fazal, A.; Irfan, M. Use of Vegetable Waste Extracts for Controlling Microstructure of CuO Nanoparticles: Green Synthesis, Characterization, and Photocatalytic Applications. J. Chem. 2017, 272179, 1-5. [CrossRef]

59. Noshad, A.; Iqbal, M.; Hetherington, C.; Wahab, H. Biogenic AgNPs-A Nano Weapon against Bacterial Canker of Tomato (BCT). Adv. Agric. 2020, 9630785. [CrossRef]

60. Rodríguez-Serrano, C.; Guzmán-Moreno, J.; Ángeles-Chávez, C.; Rodríguez-González, V.; Ortega-Sigala, J.J.; Ramirez Santoyo, R.M.; Vidales-Rodriguez, L.E. Biosynthesis of silver nanoparticles by Fusarium scirpi and its potential as antimicrobial agent against uropathogenic Escherichia coli biofilms. PLoS ONE 2020, 15, e230275. [CrossRef] [PubMed]

61. Algebaly, A.S.; Mohammed, A.E.; Abutaha, N.; Elobeid, M.M. Biogenic Synthesis of Silver Nanoparticles: Antibacterial and Cytotoxic Potential. Saudi J. Biol. Sci. 2019, 27, 1340-1351. [CrossRef] [PubMed]

62. Andleeb, S.; Tariq, F.; Muneer, A.; Nazir, T.; Shahid, B.; Latif, Z.; Ahmed Abbasi, S.; ul Haq, I.; Majeed, Z.; Ud-Din Khan, S. In vitro bactericidal, antidiabetic, cytotoxic, anticoagulant, and hemolytic effect of green-synthesized silver nanoparticles using Allium sativum clove extract incubated at various temperatures. Green Process. Synth. 2020, 9, 538-553. [CrossRef]

63. Sathishkumar, R.S.; Sundaramanickam, A.; Srinath, R.; Ramesh, T.; Saranya, K.; Meena, M.; Surya, P. Green synthesis of silver nanoparticles by bloom forming marine microalgae Trichodesmium erythraeum and its applications in antioxidant, drug-resistant bacteria, and cytotoxicity activity. J. Saudi Chem. Soc. 2019, 23, 1180-1191. [CrossRef]

64. Sreekanth, T.V.M.; Nagajyothi, P.C.; Muthuraman, P.; Enkhtaivan, G.; Vattikuti, S.V.P.; Tettey, C.O.; HwanKim, D.; Shim, J.; Yoo, K. Ultra-sonication-assisted silver nanoparticles using Panax ginseng root extract and their anti-cancer and antiviral activities. J. Photochem. Photobiol. B 2018, 188, 6-11. [CrossRef]

65. Ali, S.G.; Ansari, M.A.; Alzohairy, M.A.; Alomary, M.N.; AlYahya, S.; Jalal, M.; Khan, H.M.; Maada Asiri, S.M.; Ahmad, W.; Mahdi, A.A.; et al. Biogenic Gold Nanoparticles as Potent Antibacterial and Antibiofilm Nano-Antibiotics against Pseudomonas aeruginosa. Antibiotics 2020, 9, 100. [CrossRef]

66. Doan, V.D.; Huynh, B.A.; Nguyen, T.D.; Cao, X.T.; Nguyen, V.C.; Nguyen, T.L.H.; Le, V.T. Biosynthesis of silver and gold nanoparticles using aqueous extract of Codonopsis pilosula roots for antibacterial and catalytic applications. J. Nanomater. 2020, 8492016. [CrossRef]

67. Vimalraj, S.; Ashokkumar, T.; Saravanan, S. Biogenic gold nanoparticles synthesis mediated by Mangifera indica seed aqueous extracts exhibits antibacterial, anticancer and anti-angiogenic properties. Biomed. Pharm. 2018, 105, 440-448. [CrossRef]

68. Meléndez-Villanueva, M.A.; Morán-Santibañez, K.; Martínez-Sanmiguel, J.J.; Rangel-López, R.; Garza-Navarro, M.A.; RodríguezPadilla, C.; Zarate-Triviño, D.G.; Trejo-Avila, L.M. Virucidal Activity of Gold Nanoparticles Synthesized by Green Chemistry Using Garlic Extract. Viruses 2019, 11, 1111. [CrossRef]

69. Wu, S.; Rajeshkumar, S.; Madasamy, M.; Mahendran, V. Green synthesis of copper nanoparticles using Cissus vitiginea and its antioxidant and antibacterial activity against urinary tract infection pathogens. Art. Cells Nanomater. Biotechnol. 2020, 48, 1153-1158. [CrossRef]

70. Murthy, H.C.A.; Desalegn, T.; Kassa, M.; Abebe, B.; Assefa, T. Synthesis of Green Copper Nanoparticles Using Medicinal Plant Hagenia abyssinica (Brace) JF. Gmel. Leaf Extract: Antimicrobial Properties. J. Nanom. 2020, 3924081, 1-12. [CrossRef] 
71. Jayarambabu, N.; Akshaykranth, A.; Venkatappa Rao, T.; Rao, K.V.; Rakesh Kumar, R. Green synthesis of Cu nanoparticles using Curcuma longa extract and their application in antimicrobial activity. Mater. Lett. 2019, 259, 126813. [CrossRef]

72. Prabhu, T.Y.; Rao, V.K.; Sai, V.S.; Pavani, T. A facile biosynthesis of copper nanoparticles: A micro-structural and antibacterial activity investigation. J. Saudi Chem. Soc. 2017, 21, 180-185. [CrossRef]

73. Yugandhar, P.; Vasavi, T.; Jayavardhana Rao, Y.; Uma Maheswari Devi, P.; Narasimha, G.; Savithramma, N. Cost Effective, Green Synthesis of Copper Oxide Nanoparticles Using Fruit Extract of Syzygium alternifolium (Wt.) Walp.; Characterization and Evaluation of Antiviral Activity. J. Clust. Sci 2018, 29, 743-755. [CrossRef]

74. Naseer, M.; Aslam, U.; Khalid, B.; Chen, B. Green route to synthesize Zinc Oxide Nanoparticles using leaf extracts of Cassia fistula and Melia azadarach and their antibacterial potential. Sci. Rep. 2020, 10, 9055. [CrossRef] [PubMed]

75. Dmochowska, A.; Czajkowska, J.; Jędrzejewski, R.; Stawiński, W.; Migdał, P.; Fiedot-Toboła, M. Pectin based banana peel extract as a stabilizing agent in zinc oxide nanoparticles synthesis. Int. J. Biol. Macromol. A 2020, 165, 1581-1592. [CrossRef] [PubMed]

76. Ifeanyichukwu, U.L.; Fayemi, O.E.; Ateba, C.N. Green Synthesis of Zinc Oxide Nanoparticles from Pomegranate (Punica granatum) Extracts and Characterization of Their Antibacterial Activity. Molecules 2020, 25, 4521. [CrossRef]

77. Gilavand, F.; Saki, R.; Mirzaei, S.; Lashgarian, H.; Karkhane, M.; Marzban, A. Green Synthesis of Zinc Nanoparticles Using Aqueous Extract of Magnoliae officinalis and Assessment of its Bioactivity Potentials. Biointerface Res. Appl. Chem. 2021, 11, 7765-7774. [CrossRef]

78. Ogunyemi, S.O.; Abdallah, Y.; Zhang, M.; Fouad, H.; Hong, X.; Ibrahim, E.; Islam Masum, M.M.; Hossain, A.; Mo, J.; Li, B. Green synthesis of zinc oxide nanoparticles using different plant extracts and their antibacterial activity against Xanthomonas oryzae pv. oryzae. Art. Cells Nanom. Biotechnol. 2019, 47, 341-352. [CrossRef] [PubMed]

79. Gupta, M.; Tomar, R.S.; Kaushik, S.; Mishra, R.K.; Sharma, D. Effective Antimicrobial Activity of Green ZnO Nano Particles of Catharanthus roseus. Front. Microbiol. 2018, 9, 2030. [CrossRef]

80. Arya, S.; Sonawane, H.; Math, S.; Tambade, P.; Chaskar, M.; Shine, D. Biogenic titanium nanoparticles (TiO2 NPs) from Tricoderma citrinoviride extract: Synthesis, characterization and antibacterial activity against extremely drug-resistant Pseudomonas aeruginosa. Int. Nano Lett. 2021, 11, 35-42. [CrossRef]

81. Landage, K.S.; Arbade, G.K.; Khanna, P.; Bhongale, C.H. Biological approach to synthesize $\mathrm{TiO}_{2}$ nanoparticles using Staphylococcus aureus for antibacterial and antibiofilm applications. J. Microbiol. Exp. 2020, 8, 36-43. [CrossRef]

82. Akinola, P.O.; Lateef, A.; Asafa, T.B.; Beukes, L.S.; Hakeem, A.S.; Irshad, H.M. Multifunctional titanium dioxide nanoparticles biofabricated via phytosynthetic route using extracts of Cola nitida: Antimicrobial, dye degradation, antioxidant and anticoagulant activities. Heliyon 2020, 6, e04610. [CrossRef]

83. Mirza, A.U.; Kareem, A.; Nami, S.A.A.; Khan, M.S.; Rehman, S.; Bhat, S.A.; Mohammad, A.; Nishat, N. Biogenic synthesis of iron oxide nanoparticles using Agrewia optiva and Prunus persica phyto species: Characterization, antibacterial and antioxidant activity. J. Photochem. Photobiol. B 2018, 185, 262-274. [CrossRef]

84. Turakhia, B.; Chikkala, S.; Shah, S. Novelty of Bioengineered Iron Nanoparticles in Nanocoated Surgical Cotton: A Green Chemistry. Adv. Pharmacol. Sci. 2019, 9825969. [CrossRef]

85. Rufus, A.; Sreeju, N.; Philip, D. Synthesis of biogenic hematite $\left(\alpha-\mathrm{Fe}_{2} \mathrm{O}_{3}\right)$ nanoparticles for antibacterial and nanofluid applications. RSC Adv. 2016, 6, 94206-94217. [CrossRef]

86. Rafique, M.; Shaikh, A.J.; Rasheed, R.; Bilal Tahir, M.; Faiq Bakhat, H.; Shahid Rafique, M.; Rabbani, F. A review on synthesis, characterization and applications of copper nanoparticles using green method. Nano 2017, 12, 1750043. [CrossRef]

87. Zhang, X.F.; Liu, Z.G.; Shen, W.; Gurunathan, S. Silver nanoparticles: Synthesis, characterization, properties, applications, and therapeutic approaches. Int. J. Mol. Sci. 2016, 17, 1534. [CrossRef]

88. Mourdikoudis, S.; Pallares, R.M.; Thanh, N.T.K. Characterization techniques for nanoparticles: Comparison and complementarity upon studying nanoparticle properties. Nanoscale 2018, 10, 12871-12934. [CrossRef]

89. Carvalho, P.M.; Felício, M.R.; Santos, N.C.; Gonçalves, S.; Domingues, M.M. Application of light scattering techniques to nanoparticle characterization and development. Front. Chem. 2018, 6, 237. [CrossRef]

90. Azmi, A.; Ahyat, N.; Mohamad, F.; Hamzah, S. Synthesis of silver nanoparticles: Double-green approach of using chitosan and microwave technique towards antimicrobial activity against pathogenic bacteria. Biointerface Res. Appl. Chem. 2020, 10, 5918-5922. [CrossRef]

91. Das Mahapatra, A.; Patra, C.; Mondal, J.; Sinha, C.; Chandra Sadhukhan, P.; Chattopadhyay, D. Silver Nanoparticles Derived from Albizia lebbeck Bark Extract Demonstrate Killing of Multidrug-Resistant Bacteria by Damaging Cellular Architecture with Antioxidant Activity. ChemistrySelect 2020, 5, 4770-4777. [CrossRef]

92. Abeleda, H.E.P.; Javier, A.P.; Murillo, A.Q.M.; Baculi, R.Q. Alpha-amylase conjugated biogenic silver nanoparticles as innovative strategy against biofilm-forming multidrug resistant bacteria. Biocatal. Agric. Biotechnol. 2020, 29, 101784. [CrossRef]

93. Lakkim, V.; Reddy, M.C.; Pallavali, R.R.; Reddy, K.R.; Reddy, C.V.; Bilgrami, I.; Lomada, D. Green Synthesis of Silver Nanoparticles and Evaluation of Their Antibacterial Activity against Multidrug-Resistant Bacteria and Wound Healing Efficacy Using a Murine Model. Antibiotics 2020, 9, 902. [CrossRef]

94. Halawani, E.M.; Hassan, A.M.; Gad El-Rab, S.M. Nanoformulation of Biogenic Cefotaxime-Conjugated-Silver Nanoparticles for Enhanced Antibacterial Efficacy Against Multidrug-Resistant Bacteria and Anticancer Studies. Int. J. Nanomed. 2020, 15, 1889-1901. [CrossRef] 
95. Caires, C.S.A.; Farias, L.A.S.; Gomes, L.E.; Pinto, B.P.; Gonçalves, D.A.; Zagonel, L.F.; Nascimento, V.A.; Alves, D.C.B.; Colbeck, I.; Whitby, C.; et al. Effective killing of bacteria under blue-light irradiation promoted by green synthesized silver nanoparticles loaded on reduced graphene oxide sheets. Mater. Sci. Eng. C 2020, 113, 110984. [CrossRef]

96. Raho, R.; Nguyen, N.-Y.; Zhang, N.; Jiang, W.; Sannino, A.; Liu, H.; Pollini, M.; Paladini, F. Photo-assisted green synthesis of silver doped silk fibroin/carboxymethyl cellulose nanocomposite hydrogels for biomedical applications. Mater. Sci. Eng. C 2020, 107, 110219. [CrossRef]

97. Hussain, M.; Raja, N.I.; Mashwani, Z.-U.-R.; Naz, F.; Iqbal, M.; Aslam, S. Green synthesis and characterisation of silver nanoparticles and their effects on antimicrobial efficacy and biochemical profiling in Citrus reticulata. IET Nanobiotechnol. 2018, 12,514-519. [CrossRef] [PubMed]

98. Ibrahim, E.; Fouad, H.; Zhang, M.; Zhang, Y.; Qiu, W.; Yan, C.; Li, B.; Mo, J.; Chen, J. Biosynthesis of silver nanoparticles using endophytic bacteria and their role in inhibition of rice pathogenic bacteria and plant growth promotion. RSC Adv. 2019, 9, 29293-29299. [CrossRef]

99. Dhanasezhian, A.; Srivani, S.; Govindaraju, K.; Preetam, P.; Sasikala, S.; Ramesh Kumar, M.R. Anti-Herpes Simplex Virus (HSV-1 and HSV-2) activity of biogenic gold and silver nanoparticles using seaweed Sargassum wightii. Indian J. Geo. Mar. Sci. 2019, 48, $1252-1257$.

100. Shady, N.H.; Khattab, A.R.; Ahmed, S.; Liu, M.; Quinn, R.J.; Fouad, M.A.; Salah Kamel, M.; Bin Muhsinah, A.; Krischke, M.; Mueller, M.J. Hepatitis C Virus NS3 Protease and Helicase Inhibitors from Red Sea Sponge (Amphimedon) Species in Green Synthesized Silver Nanoparticles Assisted by in Silico Modeling and Metabolic Profiling. Int. J. Nanomed. 2020, 15, 3377-3389. [CrossRef]

101. Vinayagam, S.; Rajaiah, P.; Mukherjee, A.; Natarajan, C. DNA-triangular silver nanoparticles nanoprobe for the detection of dengue virus distinguishing serotype. Spectrochim. Acta A Mol. Biomol. Spectrosc. 2018, 202, 346-351. [CrossRef]

102. Ochoa-Meza, A.R.; Álvarez-Sánchez, A.R.; Romo-Quiñonez, C.R.; Barraza, A.; Magallón-Barajas, F.J.; Chávez-Sánchez, A.; García-Ramos, J.C.; Toledano-Magaña, Y.; Bogdanchikova, N.; Pestryakov, A.; et al. Silver nanoparticles enhance survival of white spot syndrome virus infected Penaeus vannamei shrimps by activation of its immunological system. Fish Shellfish Immunol. 2019, 84, 1083-1089. [CrossRef]

103. Benassai, E.; Del Bubba, M.; Ancillotti, C.; Colzi, I.; Gonnelli, C.; Calisi, N.; Salvatici, M.C.; Casalone, E.; Ristori, S. Green and cost-effective synthesis of copper nanoparticles by extracts of non-edible and waste plant materials from Vaccinium species: Characterization and antimicrobial activity. Mater. Sci. Eng. C Mater. Biol. Appl. 2021, 119, 11453. [CrossRef]

104. Kiriyanthan, R.M.; Sharmili, S.A.; Balaji, R.; Jayashree, S.; Mahboob, S.; Al-Ghanim, K.A.; Al-Misned, F.; Ahmed, Z.; Govindarajan, M.; Vaseeharan, B. Photocatalytic, antiproliferative and antimicrobial properties of copper nanoparticles synthesized using Manilkara zapota leaf extract: A photodynamic approach. Photodiagn. Photodyn. Ther. 2020, 32, 102058. [CrossRef]

105. Asghar, M.A.; Zahir, E.; Asghar, M.A.; Iqbal, J.; Rehman, A.A. Facile, one-pot biosynthesis and characterization of iron, copper and silver nanoparticles using Syzygium cumini leaf extract: As an effective antimicrobial and aflatoxin B1 adsorption agents. PLoS ONE 2020, 15, e0234964. [CrossRef]

106. Kumar, T.S.M.; Chandrasekar, M.; Senthilkumar, K.; Ilyas, R.A.; Sapuan, S.M.; Hariram, N.; Varada Rajulu, A.; Rajini, N.; Siengchin, S. Characterization, Thermal and Antimicrobial Properties of Hybrid Cellulose Nanocomposite Films with in-Situ Generated Copper Nanoparticles in Tamarindus indica Nut Powder. J. Polym. Environ. 2020, 29, 1134-1142. [CrossRef]

107. Li, P.; Liang, J.; Su, D.; Huang, Y.; Pan, J.; Peng, M.; Li, G.; Shan, Y. Green and efficient biosynthesis of pectin-based copper nanoparticles and their antimicrobial activities. Bioprocess Biosyst. Eng. 2020, 43, 2017-2026. [CrossRef]

108. Zhao, H.; Su, H.; Ahmeda, A.; Sun, Y.; Li, Z.; Zangeneh, M.; Nowrozi, M.; Zangeneh, A.; Moradi, R. Biosynthesis of copper nanoparticles using Allium eriophyllum Boiss leaf aqueous extract; characterization and analysis of their antimicrobial and cutaneous wound healing potentials. Appl. Organomet. Chem. 2020, e5587. [CrossRef]

109. Punniyakotti, P.; Panneerselvam, P.; Perumal, D.; Aruliah, R.; Angaiah, S. Anti-bacterial and anti-biofilm properties of green synthesized copper nanoparticles from Cardiospermum halicacabum leaf extract. Bioprocess Biosyst. Eng. 2020, 43, $1649-1657$. [CrossRef]

110. Rajivgandhi, G.; Maruthupandy, M.; Muneeswaran, T.; Ramachandran, G.; Manoharan, N.; Quero, F.; Anand, M.; Song, J.M. Biologically synthesized copper oxide nanoparticles enhanced intracellular damage in ciprofloxacin resistant ESBL producing bacteria. Microb. Pathog. 2019, 127, 267-276. [CrossRef]

111. Jagaran, K.; Singh, M. Nanomedicine for COVID-19: Potential of Copper Nanoparticles. Biointerface Res. Appl. Chem. 2021, 11, 10716-10728. [CrossRef]

112. Li, Y.; Liao, C.; Tjong, S. Recent advances in zinc oxide nanostructures with antimicrobial activity. Int. J. Mol. Sci. 2020, 21, 8836. [CrossRef]

113. Kumar, R.; Umar, A.; Kumar, G.; Nalwa, H.S. Antimicrobial properties of ZnO nanomaterials: A review. Ceram. Int. 2017, 43, 3940-3961. [CrossRef]

114. Obeizi, Z.; Benbouzid, H.; Ouchenane, S.; Yılmaz, D.; Culha, M.; Bououdina, M. Biosynthesis of Zinc oxide nanoparticles from essential oil of Eucalyptus globulus with antimicrobial and anti-biofilm activities. Mater. Today Commun. 2020, $25,101553$. [CrossRef]

115. Gomathi, R.; Suhana, H. Green synthesis, characterization and antimicrobial activity of zinc oxide nanoparticles using Artemisia pallens plant extract. Inorg. Nano-Met. Chem 2020. [CrossRef] 
116. Hou, Y.; Hou, Y.; Ren, Y.; Shi, Y.; Jin, X.; Dong, Y.; Zhang, H.C. aromaticus leaf extract mediated synthesis of Zinc oxide nanoparticles and their antimicrobial activity towards clinically multidrug-resistant bacteria isolated from pneumonia patients in nursing care. Mater. Res. Express. 2020, 7, 095015. [CrossRef]

117. Wang, P.; Jiang, L.; Han, R. Biosynthesis of zinc oxide nanoparticles and their application for antimicrobial treatment of burn wound infections. Mater. Res. Express. 2020, 7, 095010. [CrossRef]

118. Shende, P.; Kasture, P.; Gaud, R.S. Nanoflowers: The future trend of nanotechnology for multi-applications. Art. Cells Nanom. Biotechnol. 2018, 46, 413-422. [CrossRef]

119. Hasan, M.; Altaf, M.; Zafar, A.; Ali, Z.; Munawar, T.; Saif, M.S.; Tariq, T.; Iqbal, F.; WaqasKhan, M.; Mahmood, A.; et al. Bioinspired synthesis of zinc oxide nano-flowers: A surface enhanced antibacterial and harvesting efficiency. Mater. Sci. Eng. C 2021, 119, 111280. [CrossRef] [PubMed]

120. Karthik, R.; Pandiselvi, K.; Mariyappan, K.; Park, K.; Kwak, I.S.; Sivakamavalli, J. Synthesis of Biogenic Chitosan BiopolymerFunctionalized Zinc-Doped $\mathrm{Bi}_{2} \mathrm{O}_{3}$ Nanoneedles and Its Bio-applications: In Vitro Antibacterial and Anticancer activity. Arab. J. Sci. Eng. 2021. [CrossRef]

121. Li, W.; Huang, Z.; Cai, R.; Yang, W.; He, H.; Wang, Y. Rational Design of Ag/ZnO Hybrid Nanoparticles on Sericin/Agarose Composite Film for Enhanced Antimicrobial Applications. Int. J. Mol. Sci. 2021, 22, 105. [CrossRef] [PubMed]

122. Pote, A.; Pande, V.; Patel, V.; Giri, M.; Bhalke, R.; Pund, A. Design \& Development of Curcumin Loaded Zinc Oxide Nanoparticles Decorated Mesoporous Silica Liquid Stitches: A Proof of Concept in Animals. Mater. Technol. 2020. [CrossRef]

123. Husain, F.; Hasan, I.; Qais, F.; Khan, R.; Alam, P.; Alsame, A. Nanocomposite via Green Route: Attenuation of Quorum Sensing Regulated Virulence Functions and Mitigation of Biofilm in Gram-Negative Bacterial Pathogens. Coatings 2020, 10, 1190. [CrossRef]

124. Şahin, B.; Soylu, S.; Kara, M.; Türkmen, M.; Aydin, R.; Çetin, H. Superior antibacterial activity against seed-borne plant bacterial disease agents and enhanced physical properties of novel green synthesized nanostructured ZnO using Thymbra spicata plant extract. Ceram. Int. 2020, 47, 341-350. [CrossRef]

125. Imani, S.M.; Ladouceur, L.; Marshall, T.; Maclachlan, R.; Soleymani, L.; Didar, T.F. Antimicrobial Nanomaterials and Coatings: Current Mechanisms and Future Perspectives to Control the Spread of Viruses Including SARS-CoV-2. ACS Nano 2020, 14, 12341-12369. [CrossRef]

126. Ambika, S.; Sundrarajan, M. [EMIM] BF 4 ionic liquid-mediated synthesis of TiO2 nanoparticles using Vitex negundo Linn extract and its antibacterial activity. J. Mol. Liq. 2016, 221, 986-992. [CrossRef]

127. Sundrarajan, M.; Bama, K.; Bhavani, M.; Jegatheeswaran, S.; Ambika, S.; Sangili, A.; Nithya, P.; Sumathi, R. Obtaining titanium dioxide nanoparticles with spherical shape and antimicrobial properties using $M$. citrifolia leaves extract by hydrothermal method. J. Photochem. Photobiol. B Biol. 2017, 171, 117-124. [CrossRef]

128. Subhapriya, S.; Gomathipriya, P. Green synthesis of titanium dioxide $\left(\mathrm{TiO}_{2}\right)$ nanoparticles by Trigonella foenum-graecum extract and its antimicrobial properties. Microb. Pathog. 2018, 116, 215-220. [CrossRef]

129. Mobeen Amanulla, A.; Sundaram, R. Green synthesis of $\mathrm{TiO}_{2}$ nanoparticles using orange peel extract for antibacterial, cytotoxicity and humidity sensor applications. Mater. Today Proc. 2019, 8, 323-331. [CrossRef]

130. Bavanilatha, M.; Yoshitha, L.; Nivedhitha, S.; Sahithya, S. Bioactive studies of $\mathrm{TiO}_{2}$ nanoparticles synthesized using Glycyrrhiza glabra. Biocatal. Agric. Biotechnol. 2019, 19, 101131. [CrossRef]

131. Ahmad, W.; Kumar Jaiswal, K.; Soni, S. Green synthesis of titanium dioxide $\left(\mathrm{TiO}_{2}\right)$ nanoparticles by using Mentha arvensis leaves extract and its antimicrobial properties. Inorg. Nano-Met. Chem. 2020, 50, 1032-1038. [CrossRef]

132. Al-Shabib, N.A.; Mabood Husain, F.; Abul Qais, F.; Ahmad, N.; Khan, A.; Alyousef, A.A.; Arshad, M.; Noor, S.; Masood Khan, J.; Alam, P.; et al. Phyto-mediated synthesis of porous titanium dioxide nanoparticles from Withania somnifera root extract: Broad-spectrum attenuation of biofilm and cytotoxic properties against HepG2 cell lines. Front. Microbiol. 2020, 11, 1680. [CrossRef]

133. Hajipour, M.J.; Fromm, K.M.; Ashkarran, A.A.; Jimenez de Aberasturi, D.; de Larramendi, I.R.; Rojo, T.; Serpooshan, V.; Parak, W.J.; Mahmoudi, M. Antibacterial properties of nanoparticles. Trends Biotechnol. 2012, 30, 499-511. [CrossRef]

134. Gorski, C.A.; Scherer, M.M. Determination of nanoparticulate magnetite stoichiometry by Mossbauer spectroscopy, acidic dissolution, and powder X-ray diffraction: A critical review. Am. Miner. 2010, 95, 1017-1026. [CrossRef]

135. Khalil, A.T.; Ovais, M.; Ullah, I.; Ali, M.; Shinwari, Z.K.; Maaza, M. Biosynthesis of iron oxide $\left(\mathrm{Fe}_{2} \mathrm{O}_{3}\right)$ nanoparticles via aqueous extracts of Sageretia thea (Osbeck.) and their pharmacognostic properties. Green Chem. Lett. Rev. 2017, 10, 4-186. [CrossRef]

136. Unsoy, G.; Gunduz, U.; Oprea, O.; Ficai, D.; Sonmez, M.; Radulescu, M.; Alexie, M.; Ficai, A. Magnetite: From Synthesis to Applications. Curr. Top. Med. Chem. 2015, 15, 1622-1640. [CrossRef]

137. Pallela, P.N.V.K.; Ummey, S.; Ruddaraju, L.K.; Gadi, S.; Cherukuri, C.S.; Barla, S.; Pammi, S.V.N. Antibacterial efficacy of green synthesized $\alpha-\mathrm{Fe}_{2} \mathrm{O}_{3}$ nanoparticles using Sida cordifolia plant extract. Heliyon 2019, 5, e02765. [CrossRef]

138. Sharma, A.K.; Pawar, C.A.; Prasad, N.R.; Yewale, M.A.; Kamble, D.B. Antimicrobial efficacy of green synthesized iron oxide nanoparticles. Mater. Res. Express. 2018, 5, 075402. [CrossRef]

139. Vitta, Y.; Figueroa, M.; Calderón, M.; Ciangherotti, C. Synthesis of Iron Nanoparticles from aqueous extract of Eucalyptus Robusta Sm and evaluation of antioxidant and antimicrobial activity. Mater. Sci. Energy Technol. 2020, 3, 97-103. [CrossRef]

140. Ramesh, R.; Yamini, V.; Rajkumar, D.; Sundaram, S.J.; Lakshmi, D.; Ali Khan, F.L. Biogenic synthesis of $\alpha$-Fe $\mathrm{F}_{2} \mathrm{O}_{3}$ nanoparticles using Plectranthus amboinicus leaf extract. Mater. Today Proc. 2020. [CrossRef] 
141. Armijo, L.M.; Wawrzyniec, S.J.; Kopciuch, M.; Brandt, Y.I.; Rivera, A.C.; Withers, N.J.; Cook, N.C.; Huber, D.L.; Monson, T.C.; Smyth, H.D.C.; et al. Antibacterial activity of iron oxide, iron nitride, and tobramycin conjugated nanoparticles against Pseudomonas aeruginosa biofilms. J. Nanobiotechnol. 2020, 18, 18:35. [CrossRef] [PubMed]

142. Park, H.; Park, H.J.; Kim, J.A.; Lee, S.H.; Kim, J.H.; Yoon, J.; Park, T.H. Inactivation of Pseudomonas aeruginosa PA01 biofilms by hyperthermia using superparamagnetic nanoparticles. J. Microbiol. Methods. 2011, 84, 41-45. [CrossRef] [PubMed]

143. Maduray, K.; Parboosing, R. Metal Nanoparticles: A Promising Treatment for Viral and Arboviral Infections. Biol. Trace Elem. Res. 2020, 1, 18. [CrossRef]

144. Srihasam, S.; Thyagarajan, K.; Korivi, M.; Lebaka, V.R.; Mallem, S.P.R. Phytogenic Generation of NiO Nanoparticles Using Stevia Leaf Extract and Evaluation of Their In-Vitro Antioxidant and Antimicrobial Properties. Biomolecules 2019, 10, 89. [CrossRef]

145. Yaqoob, S.B.; Adnan, R.; Khan, R.M.R.; Rashid, M. Gold, Silver and Palladium nanoparticles: A chemical tool for biomedical application. Front. Chem. 2020, 8, 376. [CrossRef]

146. Hazarica, M.; Borah, D.; Bora, P.; Silva, A.R.; Das, P. Biogenic synthesis of palladium nanoparticles and their applications as catalyst and antimicrobial agent. PLoS ONE 2017, 12, e0184936. [CrossRef]

147. Vidhu, K.; Philip, D. Biogenic synthesis of $\mathrm{SnO}_{2}$ nanoparticles: Evaluation of antibacterial and antioxidant activities. Spectrochim. Acta A Mol. Biomol. Spectrosc. 2015, 134, 372-379. [CrossRef]

148. Mamonova, I.A.; Babushkina, I.V.; Norkina, I.A.; Gladkovaa, E.A.; Matatov, M.D.; Puchin'yana, D.M. Biological Activity of Metal Nanoparticles and Their Oxides and Their Effect on Bacterial Cells. Nanotechnol. Russia 2015, 10, 128-134. [CrossRef] 